\title{
CRYOVOLCANISM AND THE MYSTERY OF THE PATOM CONE
}

\author{
V. R. Alekseyev \\ P.I. Melnikov Permafrost Institute, Siberian Branch of RAS, Yakutsk, Russia \\ V.B. Sochava Institute of Geography, Siberian Branch of RAS, Irkutsk, Russia
}

\begin{abstract}
In the Earth's regions with cold climate, cryovolcanism is widespread. This phenomena is manifested as eruptions of material due to freezing of closed-type or open-type water-bearing systems which is accompanied by generation of effusive topographic forms, such as «pingo». The Patom cone is a typical structure created by cryovolcanism in fractured bedrocks of the Proterozoic age. The cone was shaped a result of the long-term, possibly multistage freezing of the hydrogeological structure during continuous and complicated phase of cryo- and speleo-genesis. The ice-saturated breccia containing limestone, sandstone and shale, which composed the cone, was subject to slow spreading due to its plastic properties; the top of the mound developed into a subsidence cone bordered by ring-shaped ramparts and a knoll in the middle, while the longitudinal profile took on an asymmetric form. The absence of soil and vegetation cover on the surface of the cone, and a relatively weak degree of weathering of the rudaceous deposits bear no evidence that the geological object is young. The question as to the age of the cone is still open.
\end{abstract}

Key words: cryovolcanism, ground heaving, pingo, bulgunnyakh, hydrolaccolith, the Patom crater.

Recommended by D.P. Gladkochub 15 August 2012

Citation: Alekseyev V.R., 2012. Cryovolcanism and the mystery of the Patom cone. Geodynamics \& Tectonophysics 3 (3), 289-307. doi:10.5800/GT-2012-3-3-0075.

\section{КРИОВУЛКАНИЗМ И ЗАГАДКА ПАТОМСКОГО КОНУСА}

\section{В. Р. Алексеев}

Институт мерзлотоведения им. П.И. Мельникова СО РАН, Якутск, Россия Институт географии им. В.Б. Сочавы СО РАН, Иркутск, Россия

Аннотация: В холодных областях Земли широко распространен криовулканизм - извержение вещества при промерзании замкнутых или открытых водоносных систем, сопровождающееся формированием эффузивных форм рельефа типа пинго. Патомский конус - характерная форма криовулканизма, проявившегося в раздробленных коренных горных породах протерозойского возраста. Формирование конуса произошло в результате многолетнего, возможно многократного промерзания гидрогеологической структуры, претерпевшей длительный и сложный этап крио- и спелеогенеза. Слагающая конус льдонасыщенная брекчия известняков, песчаников и сланцев медленно расползалась благодаря своим пластическим свойствам, при этом на вершине бугра сформировалась воронка проседания с кольцевыми валами и горкой в середине, а продольный профиль принял асимметричную форму. Отсутствие почвенного и растительного покрова на поверхности конуса, относительно слабая степень выветривания крупнообломочных отложений не являются признаками молодости геологического объекта. Вопрос о возрасте конуса остается открытым.

Ключевые слова: криовулканизм, пучение грунтов, пинго, булгуннях, гидролакколит, Патомский кратер. 


\section{1. ВВЕДЕНИЕ}

В августе 1949 г. молодой иркутский геолог В. Колпаков во время съемочных работ в безлюдной тайге на границе Якутии и Иркутской области обнаружил необычный объект, внешне напоминающий шахтный террикон. Это был усеченный конус с впадиной на вершине, сложенный крупными обломками карбонатных горных пород протерозойского возраста. Он резко выделялся на фоне окружающей местности своей формой, «белесым» цветом и «молодостью» (рис. $1, a$, б).

Через два года в журнале «Природа» геолог так описал свои впечатления: «Подобравшись ближе, я понял, что загадочный холм вовсе не дело рук человека. Скорее он напоминал идеально круглую горловину вулкана высотой в 70 метров - примерно с 25-этажный дом... Кратер был довольно свежий. Он расположился на склоне заросшей лиственницами сопки. На стенах и в самом кратере деревья еще не росли - несколько тоненьких лиственниц не в счет, - ветры не успели намести земли. Возраст аномалии я оценил в 50 - 200 лет. И еще одна загадка - поднявшись на кольцевой вал кратера, я обнаружил в самом центре впадины полукруглый купол диаметром 15 метров... Позднее, в разговорах с якутами-охотниками, я узнал, что это место называют «Гнездо огненного орла». Почему - неизвестно. И нигде в мире подобных аномалий больше нет. В инопланетян и прочие гиперборейские цивилизации я не верю. Но и разумного объяснения дать не могу» [Kolpakov, 1951, p. 57].

Сообщение В. Колпакова прокомментировал членкорреспондент АН СССР С.В. Обручев [Obruchev, 1951]. Он сделал заключение, что необычный конус это вулканическая постройка эруптивного типа, воз-

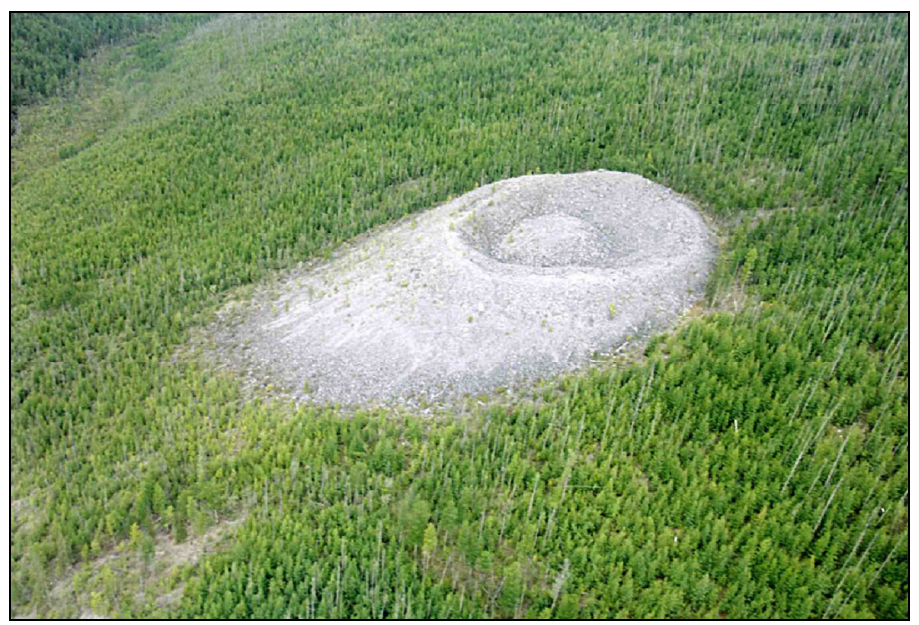

Рис. 1, a. Патомский конус. Фото с вертолета С.М. Миронова (2010 г.).

Fig. 1, $a$. The Patom cone. Photos were taken from the helicopter by S.M. Mironov (2010). никшая при локализованном прорыве глубинных газов на участке, ослабленном тектоническими разломами. В дальнейшем вопрос о происхождении Патомского конуса (его называли также Явальдинским, Джебульдинским) несколько раз обсуждался в научной литератype [Krotova, Kandyba, 1966; Portnov, 1962, 1964, 1993], не вызывая особенного ажиотажа, но в последние 5-7 лет приобрел характерные черты сенсации. Многие известные журналы и газеты предоставили свои страницы для освещения загадочного явления [Antipin, 2010; Antipin et al., 2008; Kolpakov, Yazev, 2007; Kostromitin, 2011; Moiseenko, 2011].

Изучение таежного феномена проводила большая группа известных ученых из Института земной коры СО РАН, Института геохимии им. А.П. Виноградова СО РАН, Института динамики геосфер РАН, Иркутского государственного технического университета, Иркутской астрономической обсерватории, СанктПетербургского горного университета и др. В полевых работах участвовали геологи, геохимики, геофизики, астрономы, геоботаники и даже физик-ядерщик из Давоса Отмар Бузер (Швейцария). В итоге составлена первая геологическая карта конуса (рис. 2), проведено геохимическое и минералогическое опробование, предварительное электроразведочное профилирование, выполнена магнитометрическая, металлометрическая и гравиметрическая съемки, отобраны спилы деревьев на дендрохронологический анализ, получены качественные фотоснимки с вертолетов и самолетов и пр. [Antipin et al., 2006, 2011a, 2011b; Antipin, Voronin, 2010; Antipin, Fedorov, 2008; Voronin, 2006; Golubov et al., 2011; Dmitriev A.A., Dmitriev A.G., 2011; Bemezhko

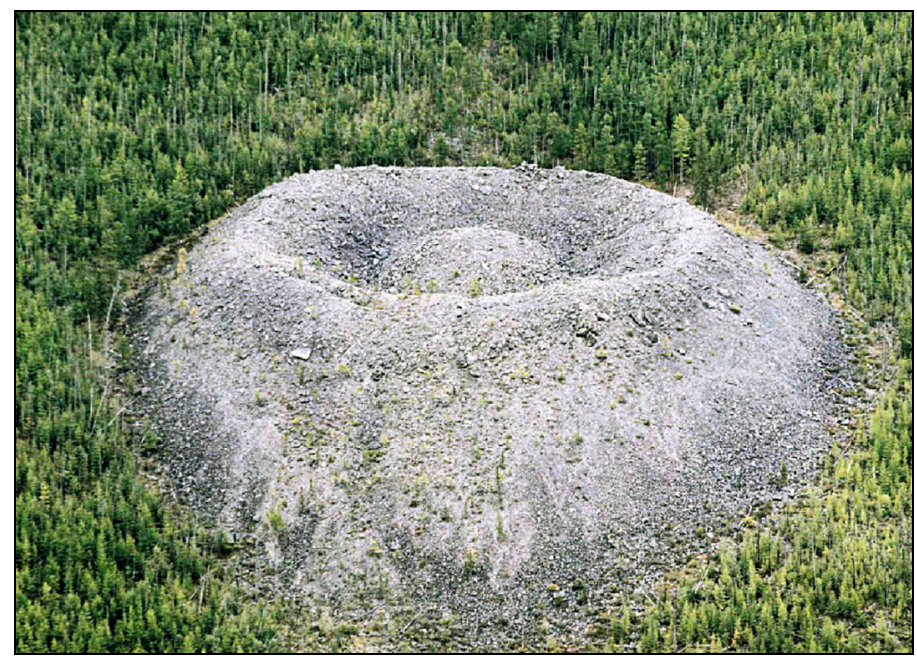

Рис. 1, б. Характерная форма Патомского кратера - усеченный конус с впадиной и горкой на вершине. Фото С.М. Миронова. http://sergey-mironov.livejournal.com/189852.html.

Fig. 1, 6 . The characteristic shape of the Patom crater - a truncated cone with a depression and a knoll in the middle. Photo by S.M. Mironov. http://sergey-mironov.livejournal.com/189852.html. 


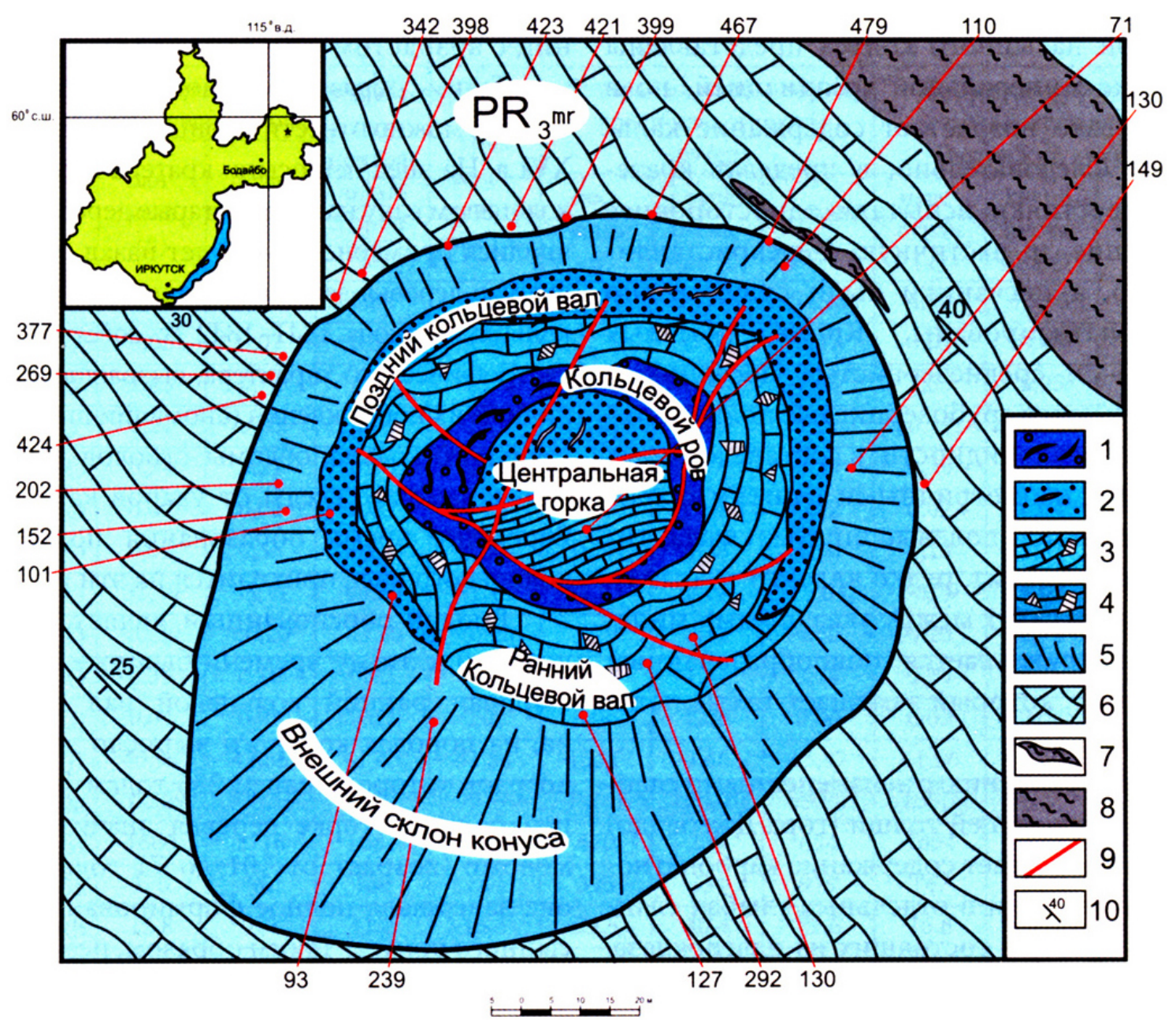

Рис. 2. Геологическая карта Патомского кратера. Составили В.С. Антипин, А.М. Федоров [Antipin et al., $2011 b] .1$ - массивные кристаллические известняки с кварц-мусковит-карбонатными жилами (кольцевой ров); 2 - массивные мелкозернистые кристаллические известняки с жилами кварца (поздний кольцевой вал и центральная горка); 3 - существенно выветрелые известняки с редкими глыбами метаморфизованных песчаников и сланцев (южная часть центральной горки); 4 - существенно выветрелые известняки с дресвой этих пород и глыбами метаморфизованных песчаников и сланцев (ранний кольцевой вал); 5 - осыпь глыб различных горных пород внешнего склона конуса; 6 - вмещающие кратер известняки мариинской свиты протерозоя; 7- прослой песчаников среди известняков; 8 - метаморфизованные песчаники; 9 - кольцевые и радиальные зоны разломов в пределах кратера; 10 - элементы залегания горных пород. На поля рисунка вынесены значения возраста лиственниц в пределах кратера и в его окружении.

Fig. 2. The geological map of the Patom crater. Compiled by V.S. Antipin and A.M. Fedorov [Antipin et al., $2011 b$ ]. 1 - massive crystalline limestone with quartz-muscovite-carbonate veins (ring-shaped rampart); 2 - massive fine-grained crystalline limestone with quartz veins (the late ringshaped rampart and the central knoll); 3 - significantly weathered limestone with occasional boulders of metamorphosed sandstone and shale (the southern part the central knoll); 4 - considerably weathered limestone with debris of these rocks and boulders of metamorphosed sandstone and shale (the early ring-shaped rampart); 5 - talus containing boulders of different rocks from the external slope of the cone; 6 - limestone of the Mariinskaya Proterozoic suites which is the crater's host rock; 7 - sandstone interlayer in limestone; 8 - metamorphosed sandstone; 9 - ringshaped and radial fracture zones within the crater; 10 - rock attitudes. Data on ages of larch trees growing in the crater and neighboring areas are given on the figure sidelines.

et al., 2011; Isaev V.P., Isaev P.V., 2011; Mironov et al., 2011; Savichev, 2011; Ugryumov, Demezhko, 2011]. История научного поиска нашла отражение в увлекательной книге журналиста А.Н. Моисеенко и астрофизика к.ф.-м.н. С.А. Язева [Moiseenko, Yazev, 2010], а также в статье С.А. Язева [Yazev, 2011].

В 2010 г. Патомский конус посетил экс-председатель Совета Федерации России Сергей Миронов, геолог по базовому образованию. С его участием 31 марта 2011 г. состоялась специальная конференции в Санкт-
Петербурском государственном горном университете им. Г.В. Плеханова, по результатам которой в Иркутске издан сборник научных статей [Savichev, 2011]. Всего со времени открытия Патомского конуса проведено семь экспедиций. Последняя поездка состоялась летом 2011 г.: выделенный МЧС России вертолет МИ-8 доставил группу ученых непосредственно в долину реки Джевальдин [Yazev, 2011]. В дальнейшем исследования планируется продолжить, причем предпринимаются попытки придать им комплексный, раз- 
носторонний характер.

В настоящее время предложено более двух десятков версий происхождения Патомского феномена. В разных вариантах они описаны в Интернете, в книге [Moiseenko, Yazev, 2010], а более обстоятельно - в серии упомянутых выше научных статей. В средствах массовой информации продолжают обсуждаться гипотезы внеземного воздействия на поверхность Земли уфологическая, метеоритная и др., хотя по результатам исследований последних лет астрономы отказались от идеи возможного падения метеорита. Четыре года назад в журнале "Холод’ОK» [Alekseev, 2007] нами коротко описан криогенный механизм образования Патомского конуса. Высказанная идея нашла последователей, в первом приближении получила признание специалистов наряду с другими версиями, однако в ряде случаев приобрела гипертрофированную форму, главным образом по причине непрофессиональной интерпретации гипотетических событий прошлого. Это обстоятельство вынуждает нас осветить предложенную версию более подробно, опираясь на современные представления мерзлотоведения и данные натурных наблюдений за развитием аналогичных форм рельефа, полученные в других регионах земного шара.

\section{2. ГИПОТЕЗЫ ПРОИСХОЖДЕНИЯ ПАТОМСКОГО КРАТЕРА}

Авторов идей, рассматривающих происхождение Патомского конуса, условно можно разделить на четыре категории: космогенисты, литогенисты, антропогенисты и криогенисты. Соответственно группируются и предложенные ими версии.

Космогенисты в своих гипотезах предполагают безусловное участие внеземных явлений - веществ, сил, процессов, цивилизаций. Например, директор Института проблем механики РАН академик Ф.Л. Черноусько считает, что воронку на вершине усеченного конуса образовал некий сверхпрочный объект, упавший с неба. В интервью Л. Картофеевой он сказал, что институт, десятки лет специализирующийся на оценках глубин проникания в грунт жестких тел, летящих с большими скоростями, воссоздал модель образования Патомского кратера. Согласно опытам, объект был цилиндрической формы, и он не взорвался, а вошел в грунт «как нож в масло» на глубину примерно 150 м. При этом он «разрезал» некую газовую линзу, которая взорвалась и вытолкнула на поверхность перекрывающие ее горные породы.

Другие гипотезы возвращают нас к событиям 1908 г., когда предположительно над Сибирью пронесся крупный метеорит и упал в бассейне Нижней Тунгуски, возбудив сейсмическую волну, три раза обогнувшую нашу планету. Часть этого небесного тела могла сформировать и Патомский кратер... По мнению уфологов, это был вовсе не метеорит, а звездный корабль инопланетян, который по неизвестной причи- не взорвался и сгорел в атмосфере, но бак с горючим из суперплотного вещества (или двигатель) вошел в земную твердь именно в том месте, где сейчас располагается Патомский конус. Остаток корабля и поныне находится в глубине нагроможденных камней-обломков...

Литогенисты опираются на известные явления, происходящие в верхней части земной коры или даже в мантии. Эндогенные процессы вызывают локальный выброс горных пород под большим давлением. Это может быть: а) разогрев ураносодержащего тела - значит там, в глубине, находятся крупные залежи радиоактивного вещества; б) катастрофический выброс метана, разложение газовых гидратов, что предполагает месторождение нефти или газа; в) формирование «молодой» алмазоносной кимберлитовой трубки; этот факт дает основание к расширению поиска алмазов под кембрийской толщей осадочных горных пород; г) миграция флюидов в поровом пространстве, по трещинам, разломам и тектонически ослабленным зонам и пр. Внезапный внутренний разогрев вещества верхней части земной коры может произойти также и в результате сверхмощного электрического разряда (удара молнии), хотя таких разрядов на Земле пока никто не наблюдал...

Антропогенисты считают образование Патомского конуса делом рук человеческих: кто-то утверждает, что в бодайбинской тайге взорвался подземный склад оружия и взрывчатых веществ, тайно устроенный после Второй мировой войны; кто-то связывает феномен с подземными испытаниями атомной бомбы, конечно, секретными; кто-то - со строительством подземного бункера или шахтными разработками «какого-то ископаемого» - в этом деле якобы участвовали узники Бодайбинлага, и т.д.

Криогенисты объясняют происхождение кратера многолетним промерзанием верхней части земной коры, формированием подземных ледников, внезапной кристаллизацией скопления переохлажденных подземных вод и пр.

Большинство из этих версий основывается на тривиальном факте увеличения объема жидкости при ее кристаллизации, некоторые явно надуманы, не соответствуют законам физики или базируются на явлениях, до сих пор не известных ни мерзлотоведам, ни гляциологам.

Так, В. Подковыров нарисовал следующую картину: «На поверхности мы видим этапную по времени образования конечную морену (КОНУС) подземного ледника, который течёт вверх по трубообразному каналу...., а начало ледника лежит на глубине более 100 м в карстовой пустоте, расположенной в известняках докембрия... Общий механизм жизни Патомского ледника не многим отличается от механизма жизни высокогорных поверхностных ледников. Постоянно подпитываемый поступающей и замерзающей на определенной глубине водой Патомский ледник по мере сво- 
его продвижения по каналу вверх выламывает из его стенок и захватывает с собой куски породы, которые в конечном итоге оказываются на дневной поверхности и образуют конус» [Podkovyrov, 2010].

Участник последней экспедиции д.г.-м.н. Д.П. Гладкочуб из Института земной коры СО РАН считает, что замерзание воды в толще горных пород вполне могло привести к гидроудару, который нарушил сплошность вмещающих карбонатных толщ и привел к формированию структуры, называемой сейчас кратером. Спусковым крючком к гидроудару мог быть самый обыкновенный оползень. Стоило по склону сдернуть карбонатную пачку, как вся энергия, накопленная замерзшей водой, передалась вверх и вызвала взрыв изнутри.

Очевидно, что в большинстве предложенных версий слишком много фантазии, поэтому во избежание недоразумений необходимо рассмотреть затронутую проблему с позиций современного мерзлотоведения.

\section{3. КРИОВУЛКАНИЗМ В ПРИРОДЕ ЗЕМЛИ}

Давно установлено, что промерзание водонасыщенных рыхло сложенных горных пород сопровождается их площадным или локализованным пучением, при этом на поверхности земли часто образуются одиночные или групповые эффузивные формы рельефа - бугры, гряды, конусы и пр. В соответствии с принципами физического подобия этот процесс с полным основанием можно назвать криовулканизмом.

Под криовулканизмом понимается извержение массы какого-либо вещества (воды, водного раствора, разжиженного грунта), возникающее в результате промерзания замкнутой или открытой водоносной системы. Это явление - характерный признак и свойство отрицательно-температурной природной среды (криосферы), претерпевающей многократные фазовые переходы в процессе своего развития [Alekseev, 2008]. На Земле криовулканизм развивается на разных уровнях организации.

Микровулканизм ярко проявляется при кристаллизации капель воды, взвешенных в свободной атмосфере или осевших на поверхности наземных и надземных предметов. Характерный пример микровулканизма капли замерзающего дождя, когда из-под ледяной оболочки под большим давлением извергаются частицы воды и намерзают на поверхности ледяной сферы в виде бугорков, конусов, натечных террас и пр.

Мезовулканизм можно наблюдать во время замерзания ручьев, луж и небольших скоплений воды в отрицательных формах рельефа земли, почвы, льда, асфальта или иного материала. Здесь также происходит периодический выброс вещества по мере его переохлаждения и кристаллизации за счет низких температур и давления образующейся корки льда. При этом на внешней стороне ледяного покрова возникают много- слойные образования, подобные вышеназванным. Аналогичные формы, но другого состава (грязевые вулканчики), образуются также при повторном промерзании частично протаявших участков мелкодисперсного грунта при ночных весенних заморозках и в период возврата холодов.

Макровулканизм характерен для промерзающих рек, озер, прудов, водохранилищ, мелководных лагун, каналов и других водных объектов, а также для верхней части земной коры. В процессе макровулканизма образуются наледи поверхностных и подземных вод, ледяные и грунтовые бугры пучения, грязевые потоки, газовые и водяные фонтаны и пр. Эти явления наиболее широко распространены в областях с суровыми климатическими условиями.

На некоторых планетах Солнечной системы проявляется мега- и гигавулканизм, когда промерзают гигантские скопления воды (или иной жидкости) на поверхности небесных тел или в их недрах. Примером проявления мегавулканизма на Марсе является конус Никс Олимпика, обнаруженный американской межпланетной станцией Маринер-9 в 1971 г. Диаметр основания этого образования 500 км, высота 27 км, ширина кратера 40 км. На Земле криогенный мега- и гигавулканизм может осуществиться при катастрофически быстром промерзании озер, морей и океанов, например в случае наступления ядерной зимы, потери атмосферы и пр.

Патомский конус, по нашему мнению, представляет собой одну из форм макровулканизма. Это типичный бугор пучения (булгуннях, пинго, гидролакколит) ${ }^{1}$, образовавшийся в результате промерзания водонасыщенных горных пород.

Причину локализованного воздымания грунтов в условиях промерзания открытой системы объяснил М.И. Сумгин на основании простейшего опыта с небольшим объемом кристаллизующейся воды [Sumgin, 1927, 1940], а в условиях промерзания закрытых структур - В.Г. Петров при изучении наледных курганов Амуро-Якутской автодорожной магистрали [Petrov, 1930, 1934]. В.Г. Петров первым указал на то, что рост бугров пучения происходит вследствие образования вакуума у нижней границы мерзлоты в результате подтаивания льда при повышении температуры на дневной поверхности. При этом вертикальное движение всей мерзлой толщи начинается с некоторым смещением во времени после нового похолодания, когда кристаллизуется прослойка воды, появившаяся вследствие подсоса воды из нижних горизонтов [Alekseev, 2008]. В дальнейшем этот механизм воспроизвел Г.М. Фельдман в морозильных камерах Института мерзлотоведения им. П.И. Мельникова СО РАН [Mel'nikov et

\footnotetext{
${ }^{1}$ В происхождении названных форм рельефа есть некоторые различия, однако при рассмотрении вопроса о механизме образования Патомского кратера они не имеют большого значения.
} 


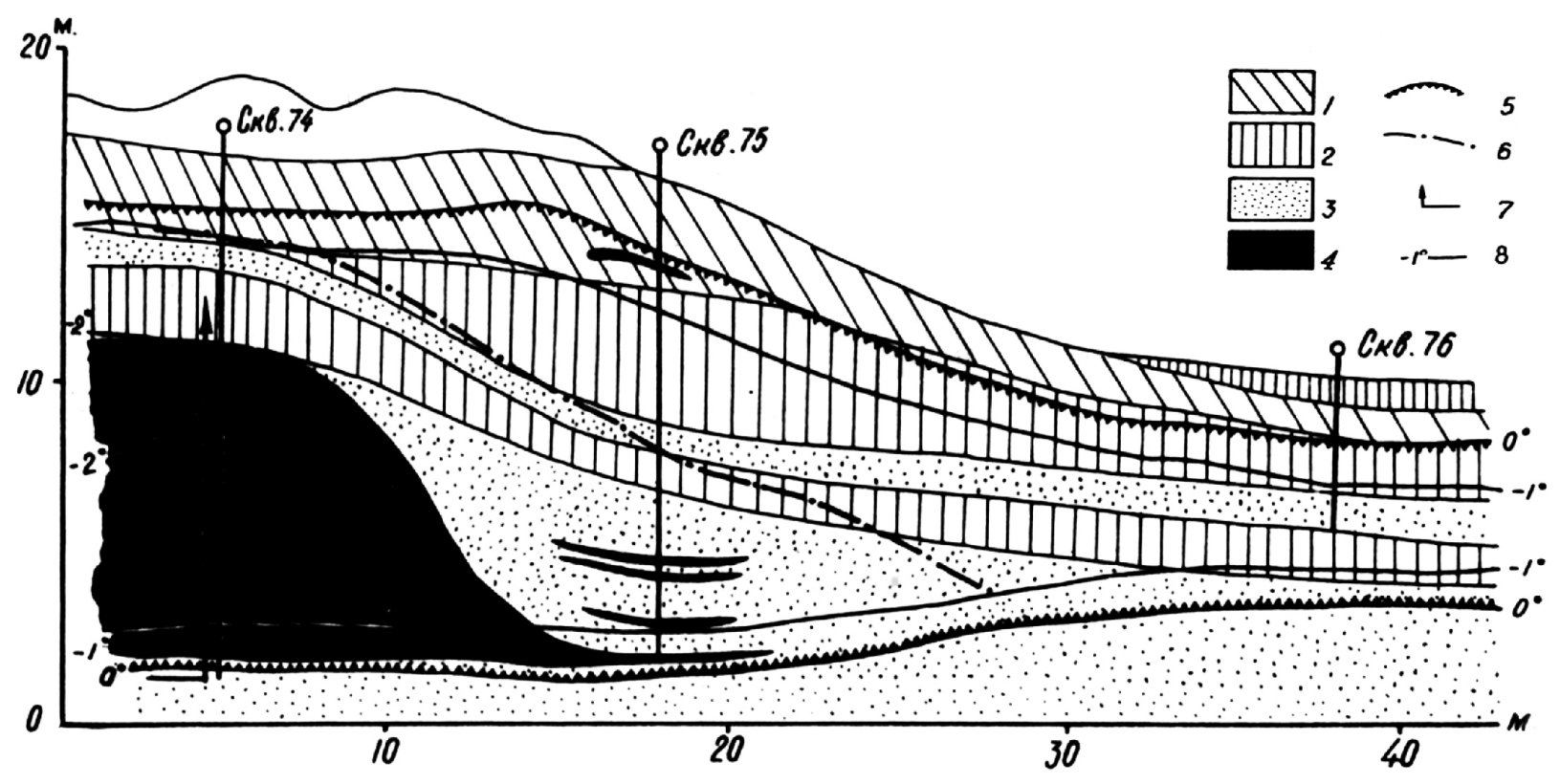

Рис. 3. Геокриологический разрез булгунняха, сформировавшегося в аласе Хотонок в окрестностях пос. Абалах, Якутия [Кatasonov, Soloviev, 1969]. 1 - супесь; 2 - суглинок; 3 - песок; 4 - лед; 5 - поверхность многолетнемерзлых горных пород; 6 - граница льдонасыщенного ядра; 7 - уровень подземных вод; 8 - изотермы, ${ }^{\circ} \mathrm{C}$.

Fig. 3. The geocryological profile of the bulgunnyakh in Alas Hotonok in the vicinity of the Abalakh settlement, Yakutia [Katasonov, Soloviev, 1969]. 1 - sandy loam; 2 - loam; 3 - sand; 4 - ice; 5 - permafrost surface; 6 - border of the ice-rich nuclei; 7 - groundwater level; 8 - isotherms, ${ }^{\circ} \mathrm{C}$.

al., 1984; Feldman, 1988], а в последнее время подтвердил экспериментами и математическими моделями Я.Б. Горелик в Институте криосферы Земли СО РАН [Gorelik, 2009, 2011].

Масштабность ежегодного формирования бугров и площадей пучения в криолитозоне поражает даже специалистов-мерзлотоведов. В холодных регионах поверхность земли зимой почти повсеместно приподнимается на 0.2-0.5 м, а летом опускается на ту же величину [Rusanov, 1961]. На участках вблизи родников промерзающий грунт часто вспучивается, трещит, лопается, перемещается за сезон на высоту до 6 м (!). Подобные курганы нередко взрываются, и из их недр извергаются газы, мощные потоки воды и грязи [Alekseev, 2008, 2011; Gevorkyan, Koreysha, 1993; Petrov, 1930; Pekhovich, Razgovorova, 1975; Sumgin, Demchinsky, 1940; Washburn, 1979; French, 2007; Mackay, 1965]. Многолетние бугры пучения встречаются практически по всей области распространения многолетнемерзлых горных пород. Наиболее крупные из них формируются на приморских равнинах Севера.

Еще в начале тридцатых годов прошлого столетия известный геоботаник В.И. Андреев [Andreev, 1936] сообщал, что в тундре Западно-Сибирской равнины он обнаружил «бугры выпячивания» высотой от 1 до 70 м. Время существования наиболее крупных из них, по мнению ученого, измеряется сотнями и тысячами лет. В.И. Андреев пришел к выводу о том, что западно-сибирские булгунняхи ничем не отличаются от якутских и образуются в результате многолетнего промерзания надмерзлотных подозерных таликов. Такой же вывод сделал А.Е. Порсилд [Porsild, 1938], наблюдая появление пинго на месте спущенного в 1900 г. озера в дельте р. Маккензи (Канада). Бугор начал расти 30 лет спустя после осушения котловины. Дальнейший рост пинго Порсилда инструментально наблюдал Росс Маккей [Mackay, 1973, 1988], который показал, что за 57 лет (с 1930 по 1987 г.) бугор вырос на 10 м, при этом в его недрах сформировалось 29700 $\mathrm{m}^{3}$ льда (объем, близкий к объему холма). В Евразии динамику, строение и распространение булгунняхов изучали многие географы и мерзлотоведы [Borovikov, 1974; Gorbunov, 1986; Gordeev, 1972; Kosmachev, 1953; Krivonosov, 1978; Minaev, 1963; Rudoy, 1988; Soloviev, 1952; Stremyakov, 1964]. Характерные особенности строения этих форм рельефа показаны на типичных геокриологических разрезах (рис. 3 и 4).

Следует заметить, что примерно до начала 60-х годов прошлого столетия холмы-конусы, сложенные рыхлыми отложениями, многие геологи, географы, геоморфологи, ландшафтоведы относили к остаткам размытых морен последнего четвертичного оледенения. В настоящее время криогенное происхождение одиночных курганов на приморских равнинах и в долинах горных рек криолитозоны ни у кого не вызывает сомнения. Остается невыясненным лишь вопрос: могут ли подобные формы рельефа образоваться при промерзании коренных (скальных) горных пород. 


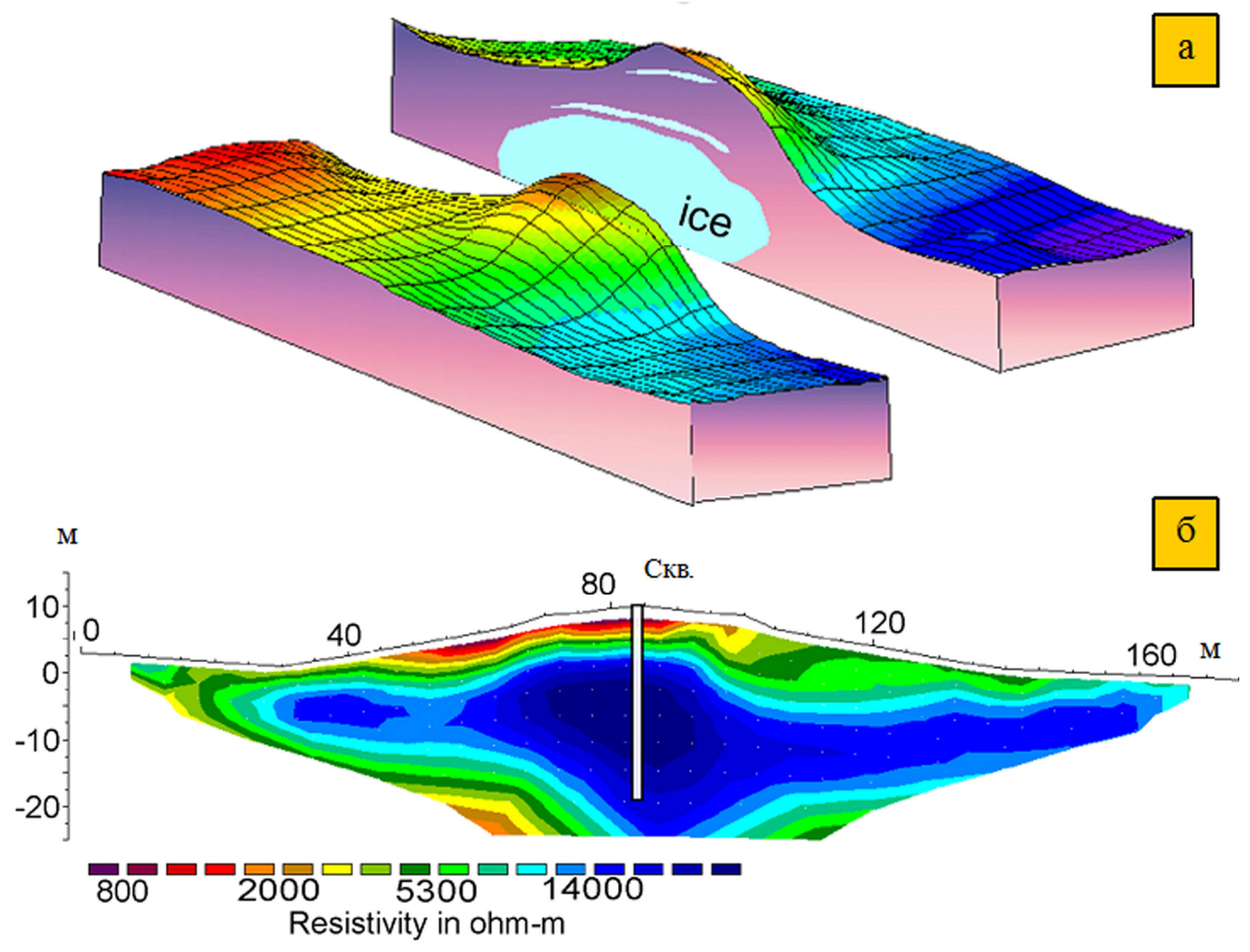

Рис. 4. Поверхностная топография (a) и электрофизический разрез (б) пинго, расположенного в долине руч. Карибу в 48 км севернее Фэрбенкса, Аляска [Yoshikawa et al., 2006]. Электрическое сопротивление более 10000 ом·м свидетельствует о присутствии ледяного ядра или льдонасыщенных горных пород.

Fig. 4. The surface topography (a) and the electro-physical profile (6) of the pingo located in the Caribou valley, 48 km north of Fairbanks, Alaska [Yoshikawa et al., 2006]. The electrical resistance above $10000 \mathrm{Om} \cdot \mathrm{m}$ gives evidence of the presence of either an ice nuclei or ice-rich rocks.

\section{4. МЕХАНИЗМ ОБРАЗОВАНИЯ ПАТОМСКОГО КОНУСА}

Известно, что верхняя часть земной коры разбита сетью многочисленных трещин, разломов, пронизана порами и каналами, закрытыми или открытыми в зависимости от глубины, степени раздробленности и состава горных пород. Обычно зона открытой трещиноватости располагается выше местного базиса эрозии. Она интенсивно продувается переменными (восходящими или нисходящими) воздушными потоками и промывается инфильтрующимися жидкими атмосферными осадками. Трещины и поры в нижней гидродинамической зоне, как правило, заполнены водой. В случае многолетнего промерзания обе зоны кольматируются льдом - в верхней зоне сублимационным и натечным, а в нижней - массивным конжеляционным. При этом промерзшая толща превращается в относительный водоупор, образуя сложную по конфигурации систему водосодержащих таликов открытого или закрытого типа. Эти талики в процессе эволюции криолитозоны могут исчезать или формироваться заново, меняясь в размерах, по форме, водосодержанию, химическому составу воды и пр.

Наибольшее количество полостей образуется в кар- стующихся карбонатных и соленосных толщах - известняках, доломитах, галогенных породах. В них в процессе седиментации и диагенеза осадков формируется сложнейшая сеть каналов, буквально пронизывающая всю толщу. В зоне распространения вечной мерзлоты полости верхней гидродинамической зоны наполняются льдом периодически, стенки их полностью или частично промерзают, растрескиваются, обрушиваются; в нижней зоне лед полностью занимает пещеры и соединяющие их ходы. В качестве примера укажем на знаменитую пещеру Хээтэй в Забайкалье, описанную еше в 1735 г. знаменитым исследователем Сибири И.Г. Гмелиным.

На рис. 5 показан вход в систему пещер Хээтэй, над которым возвышается холм, очень похожий на булгуннях. В периоды похолодания пещеры могли наполняться водой и полностью промерзать, что, естественно, вызывало дезинтеграцию вмещающих толщ, подъем кровли раздробленных и трещиноватых пород.

Пещера Хээтэй - лишь одна из тысяч ледяных полостей, известных в Прибайкалье, Саянах, на Алтае, в Приуралье, в других регионах криолитозоны. Чехол осадочных карбонатных пород Сибирской платформы, в центре которого расположился Патомский конус, 


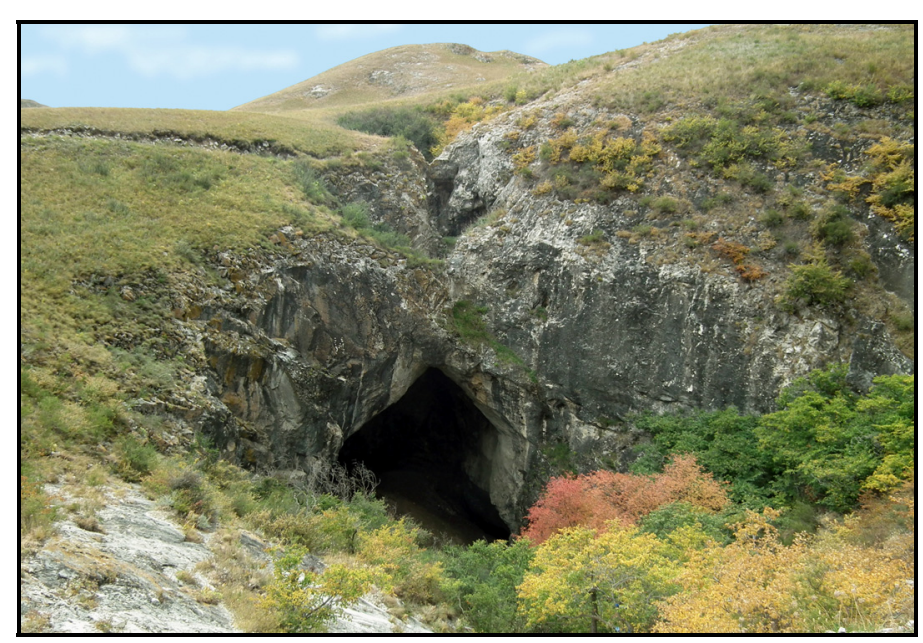

Рис. 5. Вход в пещеру Хээтэй (Забайкалье). Фото А. Бизинова (http://fotki.yandex.ru/users/byzinov/view/573457/?page=0).

Fig. 5. Entrance to cave Heetey (Transbaikalia). Photo by A. Bizinov (http://fotki.yandex.ru/users/byzinov/view/573457/?page=0).

претерпел все возможные формы спелеогенеза, а в позднем кайнозое подвергся многократному промерзанию и протаиванию. Эволюция криолитозоны, хронология событий в этой части территории недавно освещены известным мерзлотоведом и гидрогеологом С.М. Фотиевым по данным, полученным в результате реализации проекта Байкал-бурение [Fotiev, 2011]. Опираясь на эти данные, можно представить следующую картину формирования Патомского конуса.

K началу первой плиоценовой криогенной эпохи, длившейся всего 20 тыс. лет (около 3.10-3.08 млн лет назад), терригенно-карбонатные породы мариинской свиты протерозоя, слагающие конус, уже были закарстованы и раздроблены тектоническими подвижками по долинному разлому, на котором «сидит» кратер. Промерзание осадочно-метаморфической толщи было неглубоким и вряд ли вызвало существенные преобразования водообменных каналов. Однако в последующие криогенные эпохи, во вторую, плиоценовую (350 тыс. лет), и особенно в третью, плиоцен-голоценовую (1.92 млн лет), в течение которых выделено более 20 криохронов (периодов промерзания) и такое же количество термохронов (периодов протаивания и отсутствия вечной мерзлоты), произошли многократные и мощные изменения структуры гидрогеологического бассейна. В голоцене, в период очередного глубокого похолодания (около 3500-3000 лет до н.э.), он промерз на большую глубину (предположительно, до кристаллического фундамента), а в серию дальнейших периодов потепления полностью не протаял - в массиве мерзлых горных пород сформировались надмерзлотные и межмерзлотные долинные талики. В последующие криохроны (около 300 лет до н.э., 1500 лет и 300500 лет от рождества Христова) водоносный талик на месте Патомского конуса периодически промерзал, возможно не полностью. При этом происходило разламывание, дробление блоков, выдавливание льдогрунтовой брекчии и отдельных обломков; на поверхности земли возник бугор пучения (рис. 6).

Не исключается и взрывной процесс, единовременный или многократный, вызванный мгновенной кристаллизацией переохлажденной воды, заключенной во «внутреннем водяном ядре». После взрыва выброшенный обломочный материал претерпел долговременную криогенную обработку, вследствие чего на поверхности конуса сформировался покров рыхло сложенных курумообразных отложений. Наличие котловины, валов и горки на вершине бугра свидетельствует о цикличности процессов протаивания и промерзания выдавленной или выброшенной массы, что подтверждается натурными наблюдениями аналогичных структур в разных регионах криолитозоны [Borovikov, 1974; Vtyurin, 1975; Gorbunov, 1986; Gordeev, 1972; Krendelev, Nasyrova, 1985; Rudoy, 1988].

Формирование воронки, кольцевых валов и горки могло происходить также и без протаивания ядра, в процессе растягивающего движения льдогрунтовой массы, подобно тому, как движутся фронтальные уступы каменных глетчеров и курумов (средняя скорость их движения составляет 0.5 м/год) [Gorbunov, 2006]. Масса конуса, содержащая большое количество внутригрунтового льда, способна к пластическим деформациям (медленному течению), о чем могут свидетельствовать надвиги обломочного материала на растительный покров у подножия конуса, погребенные остатки деревьев и кустарников, гофрированная и ступенчатая поверхность склонов, депрессионные формы рельефа и пр. Если скорость вертикального перемещения грунтов больше скорости растекания льдогрунтовой массы, бугор растет в высоту, принимая островершинную форму; если же скорость выброса меньше скорости растягивающего движения, конус становится усеченным, уменьшается по высоте, при этом размеры воронки-провала увеличиваются. Предложенную схему трансформации геологического образования подтверждает, в частности, асимметрия Патомского конуса - склон его, обращенный в долину, вытянут, более пологий по сравнению с противоположным, нагорным склоном. В пользу этой идеи говорит также изменение уровня кольцевых валов на вершине. По наблюдениям В.В. Колпакова в 1949 г., усеченная часть конуса была строго горизонтальной [Kolpakov, 1951 ]. А.М. Портнов, обследовавший конус в 1961 г., опубликовал его схематический профиль, на котором внешний вал показан заметно ниже нагорного [Portnov, 1962, 1964]. По данным измерений И.А. Угрюмова и Д.Ю. Демежко 13 августа 2011 г., абсолютная высота внешней части вала оказалась на 12 м ниже высоты противоположного края сооружения [Ugryumov, Demezhko, 2011], т.е. плоскость среза конуса в настоящее время наклонена в сторону долины ручья Ексёкюлях.

Как видим, версия криогенного происхождения Па- 

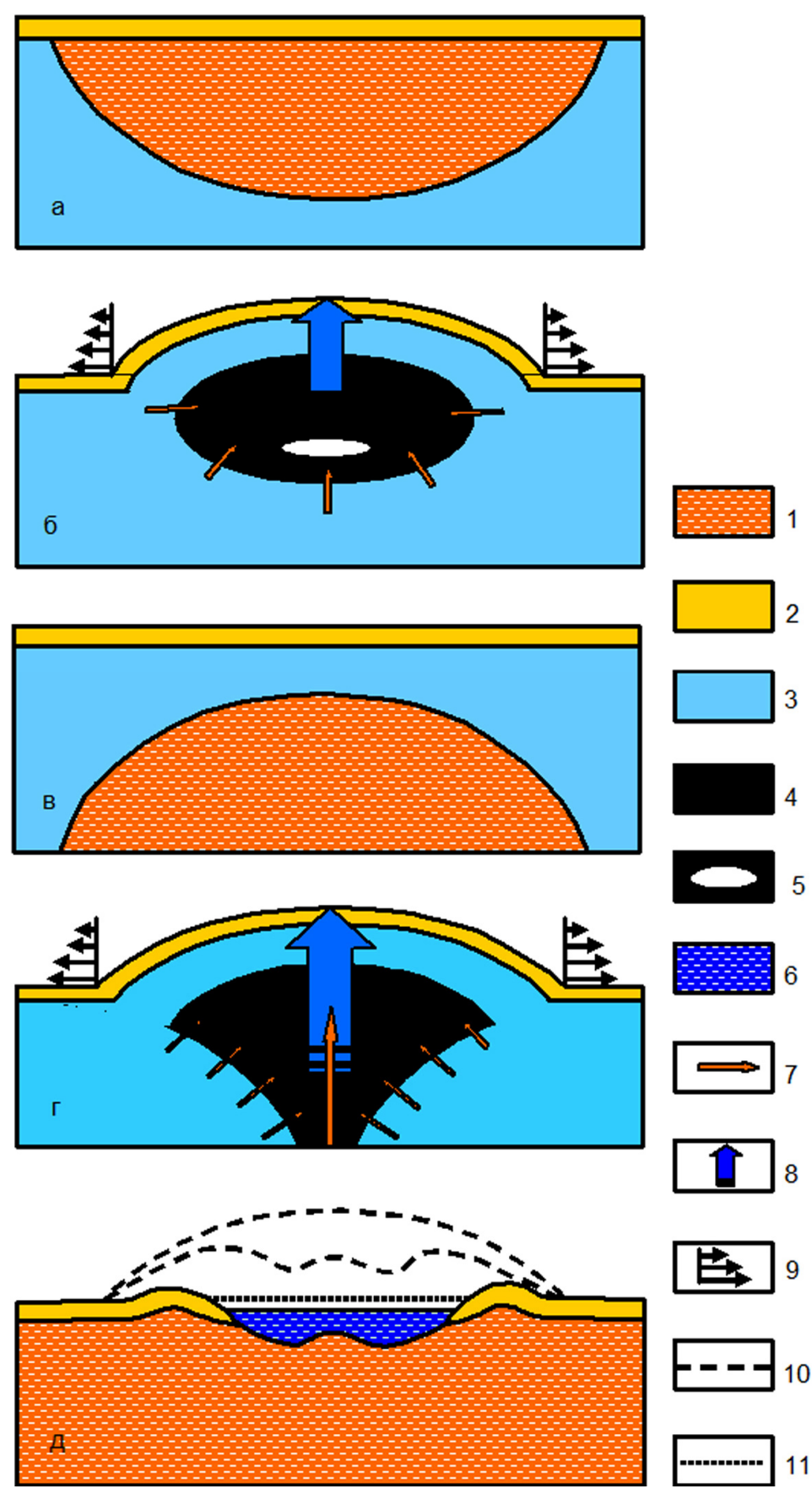

томского конуса вполне состоятельна. Она находится в соответствии не только с теоретическими представлениями о причинах и механизме криогенного движения грунтов, но и с данными экспериментальных и натурных наблюдений. Однако остается еще один очень важный вопрос, отражающий убеждения многих ученых и журналистов в части уникальности рассматриваемого объекта [Antipin, 2010; Antipin, Voronin, 2010; Kolpakov, Yazev, 2007; Moiseenko, Yazev, 2010]. Почему в бодайбинской тайге обнаружен лишь один конус, и почему аналогичные формы рельефа не встречаются в других регионах Сибири, на других континентах? Так ли это? Обратимся к независимым источникам информации.
Рис. 6. Схемы формирования бугров пучения при промерзании открытой $(a$, б) и закрытой $(6,2)$ криогидрогеологических структур. 1 - талые (непромерзающие) водоносные горные породы; 2 - сезонномерзлые и сезоннопротаивающие грунты; 3 - многолетнемерзлые горные породы; 4 подземный лед; 5 - воздушная полость в толще ледяного ядра; 6 - термокарстовое озеро на месте разрушенного бугра пучения; 7 - направление движения подземных вод при промерзании гидрогеологической структуры; 8 - вектор максимального криогенного пучения грунта и льда; 9 - эпюра скорости движения льдогрунтовой массы крупного бугра пучения; 10 - внешний контур гидролакколита в стадию максимального развития и в период цикличного многолетнего промерзания и протаивания грунтов; 11 - уровень воды при максимальном наполнении озерной котловины; д посткриогенная структура, сформировавшаяся в результате деградации мерзлых горных пород и разрушения бугра пучения.

Fig. 6. Schemes of formation of frost mounds during freezing of the open $(a, \sigma)$ and closed $(6,2)$ cryohydrogeological structures. 1 - thawed (non-frozen) water-bearing rocks; 2 - seasonally frozen and seasonally thawing rocks; 3 - permafrost; 4 - ground ice; 5 - air cavity inside the ice nuclei; 6 - thermokarst lake on the site of the destructed frost mound; 7 - direction of ground water movement during freezing of the hydrogeological structure; 8 - vector of maximum cryogenic heaving of soil and ice; 9 - diagram showing velocities of movement of the ice-soil mass of the large frost mound; 10 - outer contour of the hydrolaccolith in the maximum development stage and during the cyclic longterm phase of soil freezing and thawing; 11 - water level in case of maximum filling of the lake basin; $\partial$ - post-cryogenic structure formed due to degradation of frozen rocks and destruction of the frost mound.

\section{5. СКОЛЬКО КРИОГЕННЫХ КОНУСОВ НА ЗЕМЛЕ И ... НА МАРСЕ?}

Действительно, конус с первого взгляда поражает своей необычной формой, размерами, строением. На фоне плоскогорного рельефа и зеленой тайги он завораживает, притягивает внимание, кажется инородным образованием, т.е. создает впечатление уникальности. Однако мерзлотоведам хорошо известно, что булгунняхи-пинго, аналоги Патомского кратера, широко распространены практически по всему арктическому поясу, сложенному рыхлыми четвертичными отложениями. Р. Маккей в своей работе [Mackay, 1988] приводит карту распространения бугров пучения, на которую 

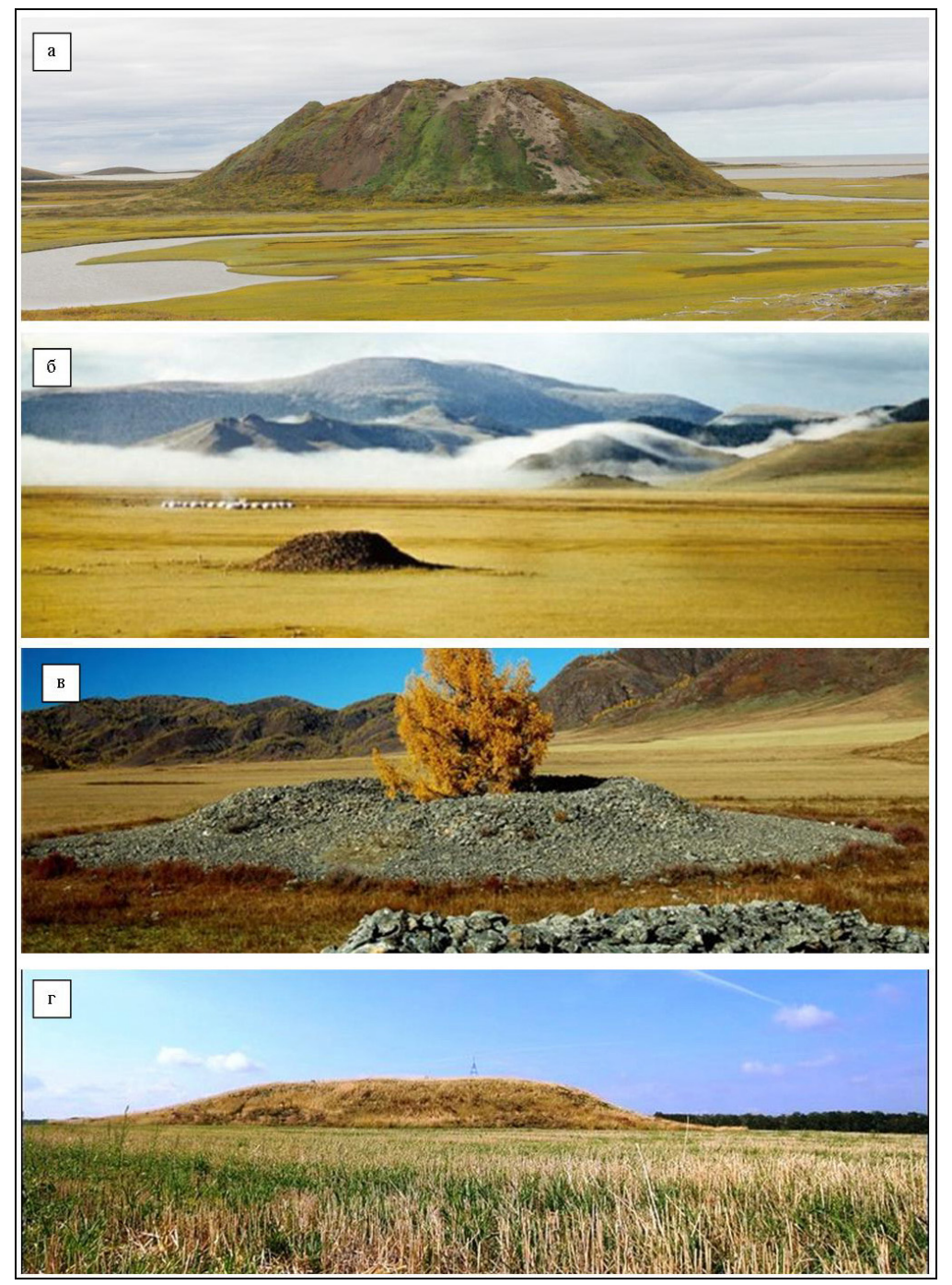

Рис. 7. Бугры пучения - аналоги Патомского конуса. $a$ - пинго на полуострове Туктояктук в Гренлании (http://tusaayaksat.files.wordpress. com/2010/10/imgp5626.jpeg); б - каменные курганы (керексуры) в горной степи Монголии (http://fictionbook.ru/static/bookimages/01/76/99/ 01769945.bin.dir/h/i_065.jpg); в - молодой каменный курган на Алтае (http://rh.foto.radikal.ru/0707/2d/d192c595fffa.jpg); г - Синий курган в Ростовской области (http://sarkel.museum-vdonsk.ru/viewtopic.php?p=285 - p305).

Fig. 7. Frost mounds as analogues of the Patom cone. $a$ - pingos in the Tuktoyaktuk Peninsula, Greenland (http://tusaayaksat.files.wordpress.com/ 2010/10/imgp5626.jpeg); 6 - stone mounds (kereksurs) in mountain steppe areas of Mongolia (http://fictionbook.ru/static/bookimages/01/76/99/ 01769945.bin.dir/h/i_065.jpg); в - young stone mound in the Altai (http://rh.foto.radikal.ru/0707/2d/d192c595fffa.jpg); 2 - the Blue mound in the Rostov region (http://sarkel.museum-vdonsk.ru/viewtopic.php?p=285 - p305).

вынесено 2000 (!) пинго. На североамериканском побережье учтено около 5000 булгунняхов, примерно 25 \% из них расположено в дельте реки Маккензи. В Гренландии зафиксировано 1500 многолетних бугров пучения. Около 200 гидролакколитов обнаружено на дне моря Бофорта. В Евразии инвентаризация крупных бугров пучения не проводилась, но из имеющихся литературных источников видно, что булгунняхи можно встретить не только на равнинах Севера, но и на Земле Франца Иосифа, в Казахстане, в горах Тянь-Шаня, в Монголии, в Тибете [Borovikov, 1974; Vtyurin, 1975; Gorbunov, 1986; Sukhodrovsky, 1964; Tarakanov, 1981], т.е. практически везде, где залегает вечная мерзлота. Даже в Нидерландах ученые обнаружили Королевское озеро, которое сформировалось на вершине древнего булгунняха, а в Уэльсе (Великобритания) описаны многочисленные кольцевые валы, сохранившиеся после вытаивания ледяных ядер гидролакколитов [Uddelermeer..., 2007]. Вообще в Западной Европе зафиксированы сотни разрушившихся бугров пучения типа пинго, оставшихся от последнего покровного оледенения [Het Drentse, 2012].

Есть также основания полагать, что многие курганы-могильники за пределами современной области распространения многолетнемерзлых горных пород (а их, по данным археологов, тысячи) представляют собой не насыпные рукотворные, а естественные образования, приспособленные для древних захоронений и 


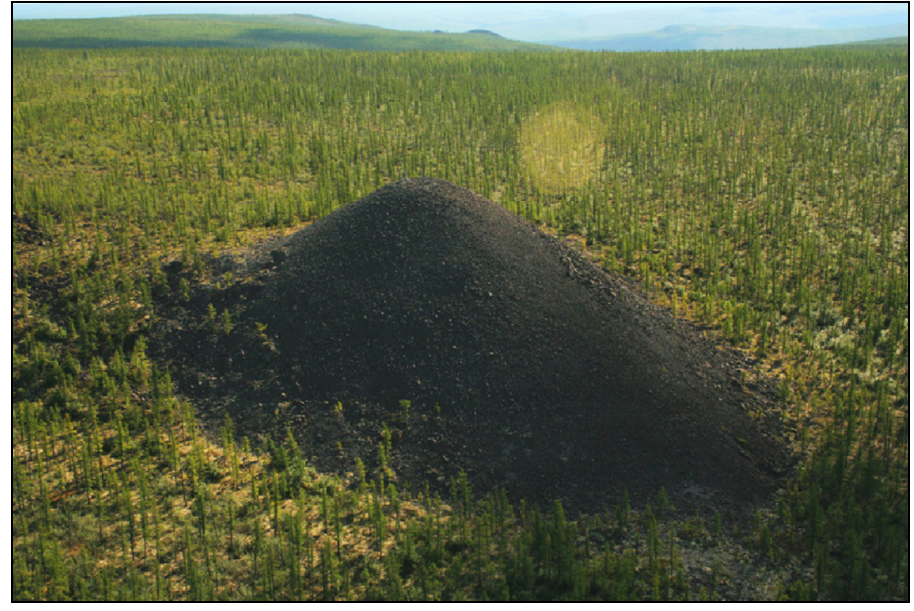

Рис. 8. Конус крупнообломочного материала в районе пос. Айхал в верхней части бассейна реки Вилюй, Якутия. Возраст образования более 100 лет. На горизонте видны еще два конуса. Фото Е. Трошина (http://oko-planet.su/phenomen/phenomennews/8986-do lina-smerti-v-yakutii.html).

Fig. 8. The cone containing coarse material in the vicinity of the Aikhal settlement in the upper part of the Vilyui river basin, Yakutia. It is more than 100 years old. At the horizon, two more cones can be seen. Photo by E. Troshin (http://oko-planet.su/phenomen/phenomennews/ 8986-dolina-smerti-v-yakutii.html).

ритуальных отправлений хуннами, скифами, сарматами, саками и другими народами, жившими здесь до нашей эры. Современные степи и даже пустыни Евразийского континента в течение голоцена и значительно ранее (в период до 3 млн лет) неоднократно подвергались глубокому промерзанию, при этом в периоды потепления и последующего нового похолодания на месте спущенных или высохших термокарстовых озер возникали крупные гидролакколиты. На равнинах они выглядели как округлые холмы, возраст которых измеряется сотнями и тысячами лет (рис. 7). Естественно, что вокруг них с давних пор концентрировалась жизнь. Кочевники использовали такие сооружения как ориентиры, как смотровые площадки, сигнальные пункты, индикаторы источников водоснабжения, места военных игрищ и пр. Какой смысл насыпать курганы для погребения усопших, затрачивая на это огромное количество времени и сил, если рядом существуют уже готовые «пирамиды», сухие, доступные, хорошо заметные? Видимо, большинство курганов-могильников все-таки создано самой природой.

Если это так, то становится очевидным, что криогенные образования рассматриваемого типа не есть феномены-одиночки, а обычное явление для всех холодных регионов Евразии и Америки.

Изучая обсуждаемую проблему, автор собрал фотографии объектов, похожих на Патомский кратер. Их сотни из разных районов земного шара. Есть и конусы, образовавшиеся из обломков коренных пород. Вот, например, снимок (рис. 8), сделанный в верхней части бассейна реки Вилюй с двухместного американского вертолета «Робинсон», управляемого пилотом-любителем С. Анановым. Это почти копия структуры из долины реки Джевальдин, только без кратера. Автор снимка Евгений Трошин высаживался на холмах, обследовал их и пришел к заключению, что они очень похожи на Патомский конус.

На рис. 9 показана священная гора Ехэ-Ёрдо высотой 34 м, расположенная в долине реки Анги в 2 км от Байкала. Гора сложена обломками гнейсов и гранитов, похожа на огромный насыпной курган. В старину вокруг нее устраивали грандиозный обрядовый праздник, который длился шесть дней и ночей. Если кольцо из танцующих не замыкалось, праздник не состоялся или считался неудачным, но такое не происходило, так как число танцующих было достаточным для образования трех и даже четырех кругов. Этнокультурный фестиваль «Ёрдынские игры» ежегодно проводится и сейчас, но материалов о внутреннем строении бугра автору найти пока не удалось. Видимо, их просто нет. А это значит, что вопрос о происхождении священной горы, в том числе и по версии криогенного поднятия или насыпного кургана-могильника, остается открытым.

Криовулканизм может проявляться не только в закарстованных карбонатных породах, но и в эффузивных толщах. Во многих районах Сибири четвертичные вулканы возникли уже после того, как сформировалась мощная толща вечной мерзлоты. Излияние трещинного типа сопровождалось разливом лавы по долинам рек и формированием под раскаленными породами сквозных таликов. В Восточных Саянах и Прибайкалье извержения происходили из-под некоторых ледни-

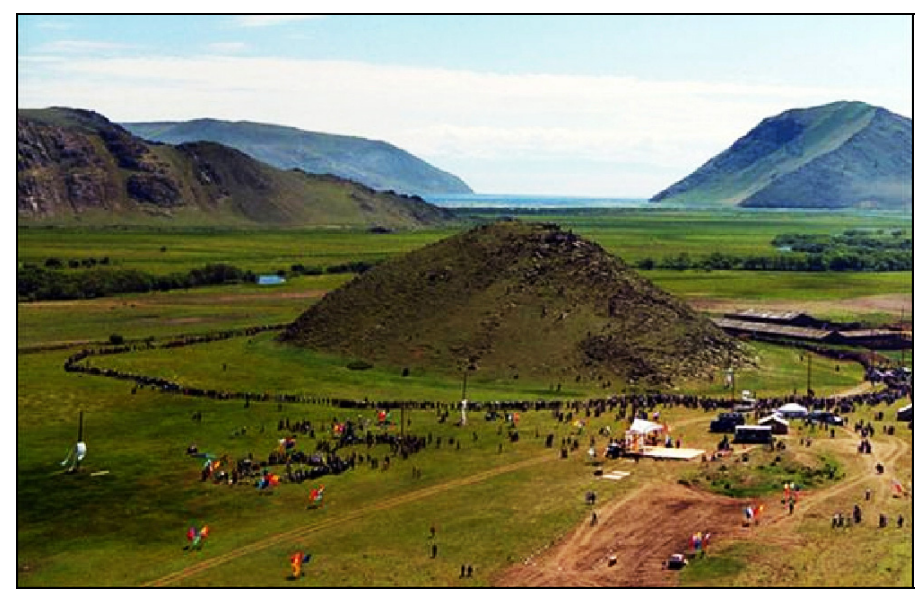

Рис. 9. Священная гора Ехэ-Ёрдо в Прибайкалье, похожая на криовулкан (http://kedr.marshruty.ru/Photos/Photo.aspx?PhotoID= f37b0387-e7ea-43ea-958d-6ae21958f512\&Size=XL).

Fig. 9. Sacred Mountain Yehe-Erdo in the Pribaikalie. It looks like a cryo-volcano (http://kedr.marshruty.ru/Photos/Photo.aspx?PhotoID= f37b0387-e7ea-43ea-958d-6ae21958f512\&Size=XL). 


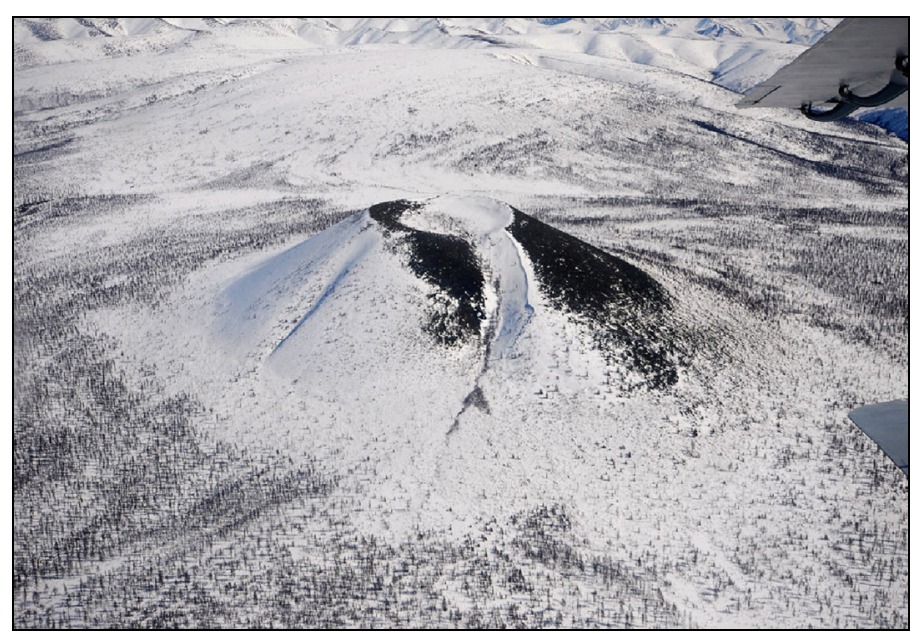

Рис. 10. Конус вулкана Балаган-Тас в бассейне р. Индигирка, похожий на гигантский булгуннях. Фото Сандро (http://img-fotki. yandex.ru/get/4909/sandro1.4b/0_6020b_e9345b84_orig).

Fig. 10. The cone of the Balagan-Tas volcano in the basin of the Indigirka river. It looks like a giant bulgunnyakh. Photo by Sandro (http://img-fotki.yandex.ru/get/4909/sandro1.4b/0_6020b_e9345b84_ orig).

ков [Grossvald, 2003]. В последующие крио- и термохроны остывшая лава многократно промерзала, при этом так же, как и протерозойские известняки и песчаники Патомского нагорья, могла вспучиваться и приобретать все характерные черты как вулканов центрального типа, так и зрелых бугров типа пинго. Криогенной деформации, в том числе просадкам, провалам в результате вытаивания подземного льда, подвергались шлаковые конусы и покровы. Приведем характерные примеры.

В бассейне реки Индигирки, в 12 км от Большой Момской наледи, расположен конус вулкана БалаганТас (рис. 10). Высота его 300 м, диаметр в основании 1200 м, ширина блюдцеобразной воронки на вершине 130 м, глубина 30 м. Предполагают, что раньше в воронке располагалось озеро, но затем оно было спущено по глубоким эрозионным рытвинам, похожим на трещины пучения. Конус сложен обломками туфа с примесью вулканических бомб, зарос кустарником, а в нижней части - редкостойным лиственничным лесом. Предположительно возраст конуса около 500 лет. По всем признакам Балаган-Тас - это молодой вулкан. Но морфологически его можно идентифицировать также и как мощный булгуннях.

Другой пример - Долина вулканов в Восточных Саянах. Здесь проявился очевидный глубинный вулканизм. Дно долины покрыто застывшей лавой, которая местами прорвана извержениями центрального типа (рис. 11). Имеется несколько шлаковых конусов, больших и малых (вулканы Кропоткина, Перетолчина и др.), сформировавшихся, видимо, в начале голоцена (8-10 тыс. лет назад). Часть конусов разрушена. В по- токах лавы встречаются провалы. Конечно, весь этот вулканический комплекс за указанный период времени промерзал. И не один раз. Видимо, он и сейчас находится в многолетнемерзлом состоянии. Трудно представить, чтобы насыщенная водой пористая масса горных пород при промерзании и протаивании не деформировалась, не вспучивалась и не подвергалась термокарстовым процессам. Криогенез этой сложной структуры, безусловно, отразился на ее внешней, морфологической стороне, и это обстоятельство позволяет предположить, что некоторые вулканические постройки (или часть их) либо образовались в результате последующего морозного пучения, либо были существенно преобразованы, модифицированы этим процессом. Не исключено, что ядро некоторых вулканов состоит изо льда или льдогрунтовой брекчии. Разрешить эти вопросы могут только специальные исследования.

В последние годы в связи с осуществлением дальних космических экспедиций активно обсуждается вопрос о криовулканизме на холодных планетах Солнечной системы, в частности на Марсе [Hauber et al., 2011]. На основе методов сравнительной планетологии, хотя и гипотетически, выявлены особенности строения и основные свойства криосферы Марса, зафиксировано огромное количество структур криогенного происхождения - ледники, каменные глетчеры, термокарстовые провалы, солифлюкционные потоки, ледяные русла рек и пр. Снимки высокого разрешения, сделанные с космических аппаратов «Марс», «Mariner», «Viking» и др., позволили с высокой степенью вероятности идентифицировать многие марсианские кратеры как гигантские гидролакколиты (рис. 12). По

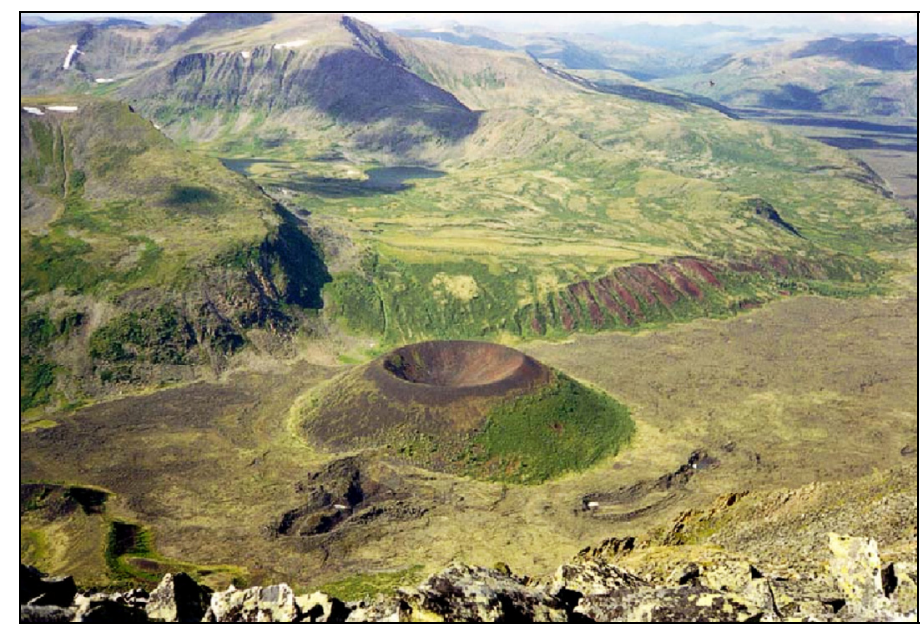

Рис. 11. Конус вулкана Кропоткина в Восточных Саянах, обработанный криогенными процессами (http://www.paranormal-news .ru/_tbkp/bull/2476.jpg).

Fig. 11. The cone of the Kropotkin volcano in the Eastern Sayan. It was impacted by cryogenic processes (http://www.paranormal-news .ru/_tbkp/bull/2476.jpg). 


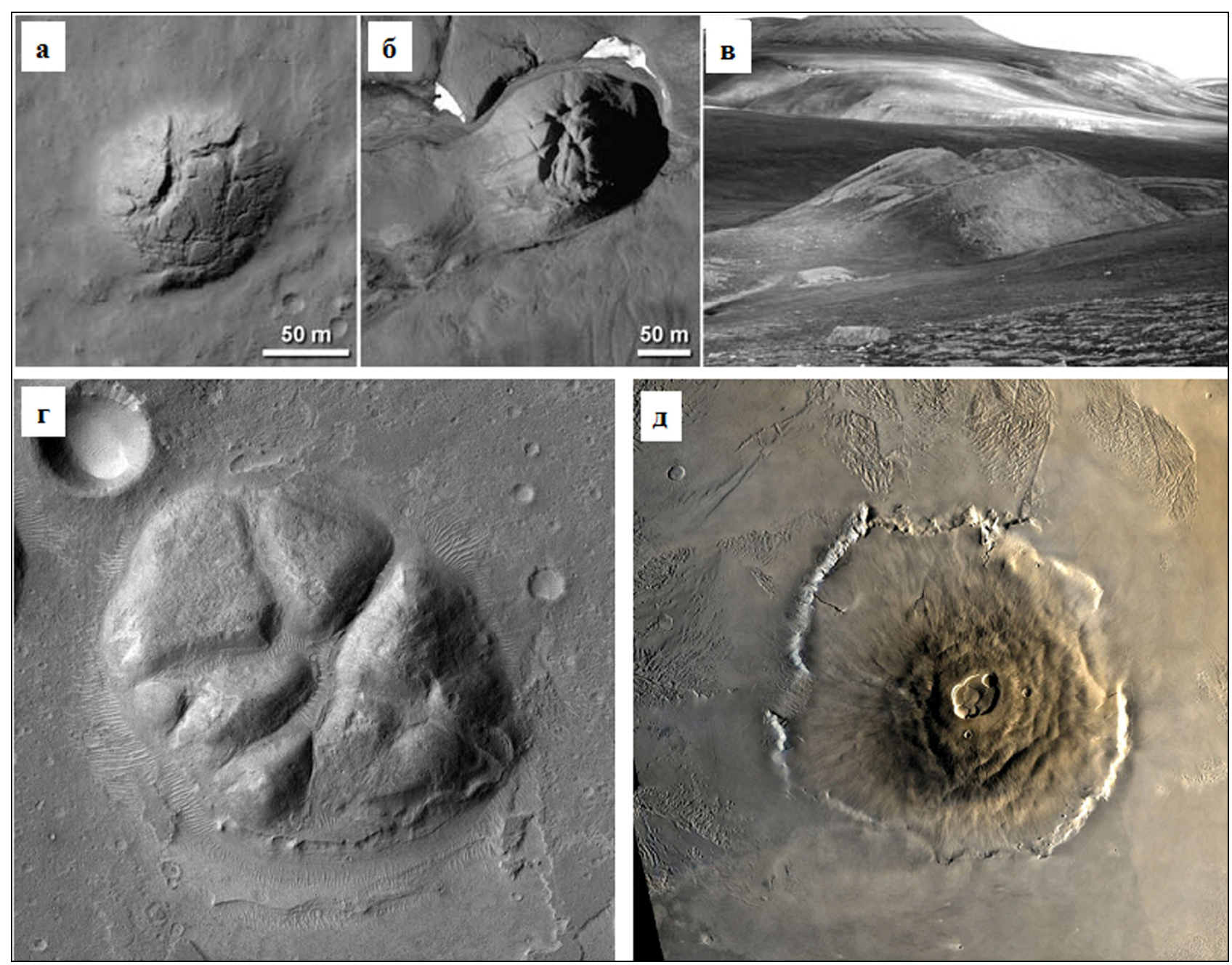

Рис. 12. Характерная форма гидролакколитов на Земле и на Марсе. $a$ - разрушающийся бугор пучения на Марсе; $б$ - пинго в центральной части архипелага Шпицберген (аэрофотоснимок); в - тот же бугор пучения (наземный снимок) [Hauber et al., 2011]; NASA/JPL/ UofA, DLR and DLR/Ernst Hauber; 2 - разрушенный пинго на Марсе диаметром 4 км (http://themis.asu.edu/node/5387); $\partial$ - гигантский бугор пучения диаметром около 500 км, образовавшийся на Марсе вследствие излияния глубинной «водяной лавы» (NASA/JPL-Caltech/ MSSS).

Fig. 12. The characteristic shape hydrolaccoliths on the Earth and Mars. $a$ - crumbling mound on Mars; $\sigma$ - pingo in the central part of the Spitsbergen archipelago (aerial photo); 8 - the same mound (ground shot) [Hauber et al., 2011]; NASA/JPL/UofA, DLR and DLR/Ernst Hauber; 2 destroyed pingo (its diameter amounts to $4 \mathrm{~km}$ ) on Mars (http://themis.asu.edu/node/5387); $\partial$ - giant mound (its diameter is about $500 \mathrm{~km}$ ) on Mars, which results from deep «water lava» eruption (NASA / JPL-Caltech/MSSS).

ориентировочным оценкам возраст этих образований достигает 100 тыс. лет. Все это дает основание для оптимистического вывода о важной роли низких температур в формировании и развитии геологической среды, в том числе и загадочного «кратера», обнаруженного в сибирской тайге.

\section{6. О ВОЗРАСТЕ ПАТОМСКОГО КОНУСА}

В решении проблемы происхождения Патомского конуса важное значение имеет определение времени его образования. Первооткрыватель В.В. Колпаков определил возраст конуса в 50-200 лет. Анализ спилов деревьев, произведенный в 1963 г. сотрудниками экс- педиции Сибирской комиссии по метеоритам и космической пыли [Krotova, Kandyba, 1966], показал возраст не менее 250-300 лет. По данным исследований дендролога В.И. Воронина [Antipin et al., 2011b; Voronin, 2006] эта цифра увеличилась на 100-150 лет, и теперь уже считается доказанным, что бугор возник примерно 450-500 лет назад, при этом во многих случаях слово «не менее» опускается. Такой ли уж молодой Патомский конус? Попробуем разобраться.

С поверхности курган покрыт крупными, хаотически сложенными обломками известняка, кристаллических сланцев и песчаников (рис. 13). Местами видны крупные, разноориентированные блоки, разваливающиеся «на глазах». Некоторые удаленные друг от друга обломки еще недавно составляли одно целое - их 


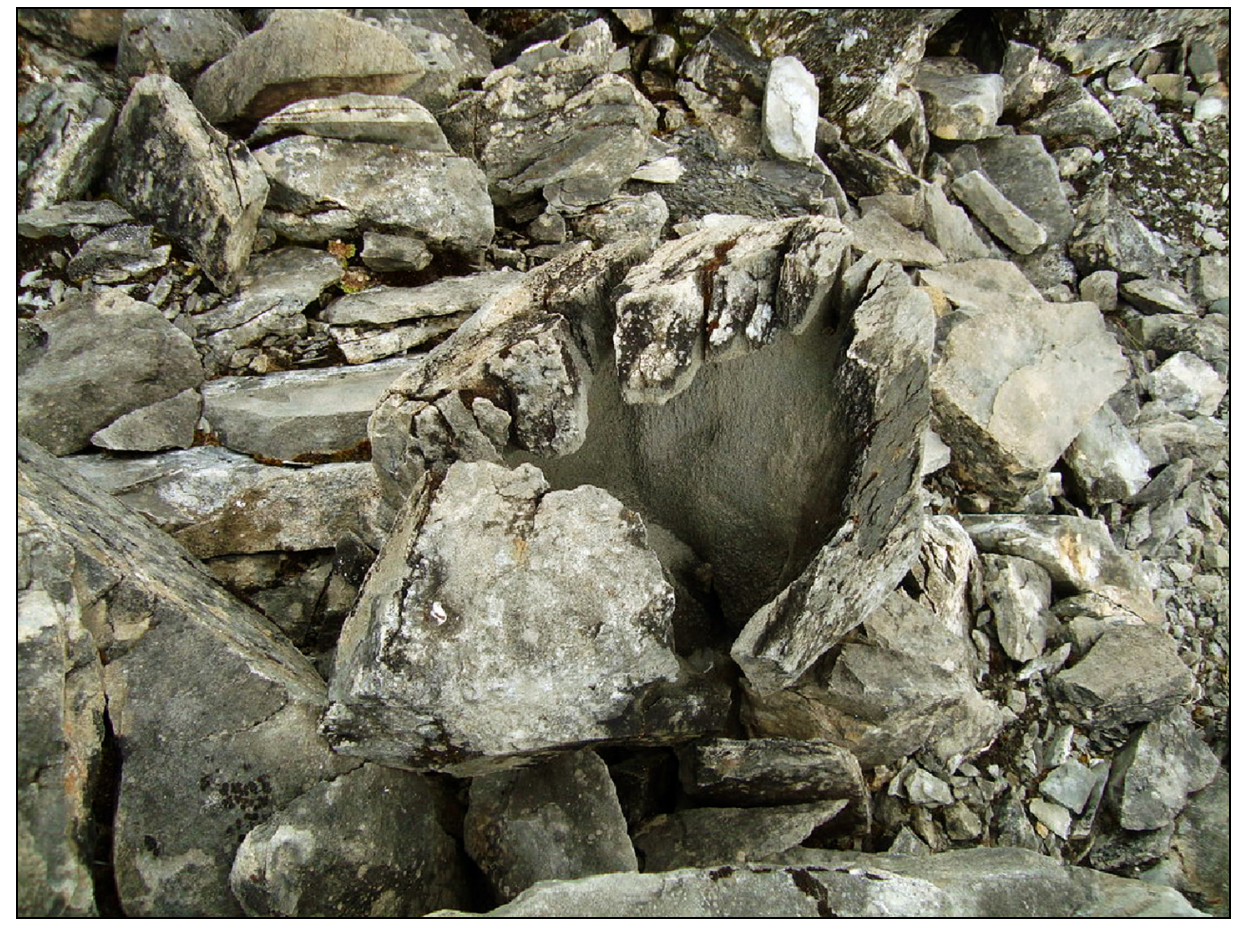

Рис. 13. Крупнообломочные отложения на склоне Патомского конуса. Фото Ю. Вигеля (http://limatroads.blogspot.com/2010/10/blog-post 25.html).

I Fig. 13. Coarse sediments on the slope of the Patom cone. Photo by Yu. Vigel (http://limatroads.blogspot.com/2010/10/blog-post_25.html).

нетрудно соединить. Сведения о проходке шурфов, посредством которых можно было бы установить более глубокое строение покровных отложений и состав ядра, отсутствуют. Имеется лишь одно указание на выработку глубиной 1.8 м у подножия конуса с восточной стороны [Krotova, Kandyba, 1966]. В забое выемки зафиксирована верхняя граница мерзлоты, а также указано, что в толще раздробленных горных пород обнаружено погибшее дерево. В выемке наблюдался обильный приток воды, что не позволило углубить шурф. Нет сведений и о попытках выяснить внутреннее строение конуса посредством бурения.

По наблюдениям 3.А. Кротовой и Ю.Л. Кандыба летом 1961 г., часть серповидного вала в кратере была «густо покрыта растительностью (лиственница, пихта, кустарник, лишайники). Возраст этих деревьев до 100 лет». Куда девалась «лесная опушка» - не известно. На современных фотографиях видны лишь единичные стволы деревьев, а поверхность конуса выглядит как типичный курум. Странно, что побывавшие там геологи пока не заложили ни одного шурфа, ни одной канавы. Видимо, разобрать каменные развалы без специальных приспособлений и техники оказалось невозможным.

Курумы - характерная разновидность криогенных склоновых отложений, широко распространенная в гольцах и в верхней части лесного пояса Сибири, Чукотки, Урала, других горных регионов криолитозоны. Крупные, рыхло сложенные и подвижные обломки пород обычно подстилаются постепенно измельчающимися фракциями, вплоть до дресвы, причем мелкозем, в том числе и возможный гумус - животворная часть почвы, выносится потоками надмерзлотных вод за пределы криогенных отложений. Весной, в период снеготаяния, курум наполняется льдом, во время формирования которого происходят подвижки, вымораживание обломков, их сортировка, а вся масса льдогрунта медленно сползает вниз по склону. Вот почему на поверхности курумов отсутствует растительный покров. Вспомним крупнообломочные отвалы шахт и карьеров в Хибинах, в Якутии, на Чукотке - они не зарастают, хотя возраст многих их них превышает 50-70 лет.

В естественных условиях процесс курумообразования особенно активно протекает в периоды похолодания, но ярко проявляется и в современную климатическую фазу - все зависит от состава пород и гидротермических условий криогипергенеза. Возраст курумов на современном этапе исследований определить невозможно, так как они сплошным чехлом покрывают горные массивы самого разного состава и возраста от архея до четвертичных вулканических формаций. Все курумы молодые и все одновременно старые. Когда они возникли? Согласно геокриологической летописи С.М. Фотиева [Fotiev, 2011], видимо, в течение позднего кайнозоя (3.1-0.0 млн лет назад). А это значит, что Патомский конус мог появиться в любой «момент» указанного периода и существовать многие 
тысячи лет. И действительно, возраст некоторых гидролакколитов на побережье Северной Америки оценивается в пределах 4-7 тыс. лет [William et al., 1968], причем период их формирования растягивался на тысячи лет. Радиоуглеродный анализ торфа, перекрывающего булгуннях высотой 17 м в долине реки Евояхи на севере Западно-Сибирской равнины, показал, что бугор начал расти 5000 лет назад и продолжал увеличиваться в объеме со скоростью 2-3 см/год в течение 2500 лет [Vasilchuk, Budantseva, 2010].

При реконструкции событий прошлого следует также иметь в виду, что некоторые деревья в зоне вечной мерзлоты имеют возраст значительно старше, чем образовавшиеся под ними криогенные формы рельефа. Например, гидролакколит сформировался в зиму текущего года, а деформированные, но ныне здравствующие лиственницы на нем к этому моменту прожили уже по 300-400 лет. На Патомском конусе аналогичная ситуация: деревья и кустарники могли поселиться как после воздымания грунта, так и до начала роста бугра и подняться вместе с ним. В связи с этим использовать данные дендрохронологического анализа при изучении бугра пучения нужно осмотрительно и осторожно.

Как видим, проблема определения возраста Патомского конуса даже в рамках периода 450-500 лет не такая простая. Внешние признаки «свежести» конуса, сформировавшиеся за счет активных экзогенных процессов, еще не доказывают молодость всего геологического образования.

\section{7. ЗАКЛЮЧЕНИЕ}

1. В холодных областях Земли и на некоторых планетах Солнечной системы широко распространен криовулканизм - извержение вещества при промерзании замкнутых или открытых водоносных систем, сопровождающееся формированием бугров пучения типа «пинго» или эффузивных покровов типа «наледи». Криовулканизм является характерным признаком и свойством криосферы; он имитирует излияние магмы и может влиять на морфоструктуру и развитие вулканических построек другого происхождения.

2. Патомский конус - характерная форма криовулканизма, проявившегося в коренных горных породах протерозойского возраста. Конус возник в результате многолетнего, возможно многовекового и тысячелетнего промерзания водоносной гидрогеологической структуры, претерпевшей длительный и сложный этап крио- и спелеогенеза, по меньшей мере в течение 2.5-3.0 млн лет. Дезинтеграция слагающих структуру горных пород, снижение их прочности обусловлены суммарным воздействием тектонических, криологических и гидрогеологических процессов, предшествующих субвертикальному перемещению материала и/или его циклическому выбросу. Образовавшийся конус из льдонасыщенной брекчии медленно расползался благодаря приобретенным пластическим свойствам, при этом на его вершине сформировалась воронка проседания с кольцевыми валами и горкой в середине, а продольный профиль принял асимметричную форму. Конус и сейчас подвержен деформациям течения, десерпции, активному криогенному разрыхлению и подповерхностой обработке надмерзлотными водами. Отсутствие почвенного и растительного покрова на поверхности конуса, «белесый» цвет обломков горных пород, их «свежий» излом, неустойчивое, подвижное состояние не являются признаками молодости геологического образования.

3. Для окончательного вывода о происхождении, времени формирования и развития Патомского конуса необходимы специальные мерзлотно-гидрогеологические, геотермические и геофизические исследования: бурение скважин, проходка шурфов и канав, вертикальное электрическое зондирование, определение абсолютного возраста погребенных остатков древесины и пр.

\section{8. ЛИТЕРАТУРА}

Alekseev V.R., 2007. Hydrovolcanism in the cryosphere of the Earth. Kholod'OK 1 (4), 6-12 (in Russian) [Алексеев В.P. Гидровулканизм в криосфере Земли // Холод’ОК. 2007. Т. 1. № 4. С. 6-12].

Alekseev V.R., 2008. Cryology of Siberia. Publishing House of SB RAS, GEO Branch, Novosibirsk, 483 p. (in Russian) [Алексеев В.Р. Криология Сибири. Новосибирск: Изд-во СО РАН, Филиал «ГЕО», 2008. 483 с.].

Alekseev V.R., 2011. We Live on the Permafrost. Publishing House of the Permafrost Institute, SB RAS, Yakutsk, 72 p. (in Russian) [Алексеев B.P. Мы живем на вечной мерзлоте. Якутск: Изд-во Института мерзлотоведения СО РАН, 2011. 72 c.].

Andreev V.I., 1936. Hydrolakkolites (bulgunnyakhi) in the West Siberian tundra zones. Izvestiya gosudarsvennogo geograficheskogo obshchestva 68 (2), 186-210 (in Russian) [Андреев В.И. Гидролакколиты (булгунняхи) в Западно-Сибирских тундрах // Известия государственного географического общества. 1936. Т. 68. № 2. С. 186-210].

Antipin V.S., 2010. Patomsky Crater - the unique geological object in Eastern Siberia. Science in Siberia 43 (2778).

Antipin V.S., Arsentiev A.L., Voronin V.L. et al., 2006. Survey of Patom Crater. Selected Problems of Astronomy. Proceedings of the Sky and the Earth Conference dedicated to the 75th anniversary of the Astronomical Observatory of the Irkutsk State University. Irkutsk, 2006. P. 163-168 (in Russian) [Антипин В.С., Арсентьев АЛ., Воронин В.Л. и др. Экспедиционное обследование Патомского кратера // Избранные проблемы астрономии: Материалы научно- 
практической конференции «Небо и Земля», посвященной 75-летию астрономической обсерватории ИГУ. Иркутск, 2006. С. 163-168].

Antipin V.S., Fedorov A.M., 2008. The origin of Patom Crater, East Siberia, from geological and geochemical data. Doklady Earth Sciences 423 (9), 1335-1339. http://dx.doi.org/10.1134/S1028334X08090018.

Antipin V.S., Fedorov A.M., Dril' S.I., Voronin V.I., 2011a. The new data on the origin of the Patom Crater (East Siberia). Doklady Earth Sciences 440 (2), 1391-1395. http://dx.doi.org/10.1134/S1028334X11100187.

Antipin V.S., Fedorov A.M., Voronin V.I., 2011b. Patom Crater in Eastern Siberia (its structure, age and conditions of origin). In: Patom Crater. Research in the 21st century. Publishing House of the Irkutsk State University, Irkutsk, p. 30-41 (in Russian) [Антипин B.C., Федоров А.М., Воронин В.И. Патомский кратер в Восточной Сибири (строение, возраст и условия образования) // Патомский кратер. Научные исследования в XXI веке. Иркутск: Изд-во Иркутского госуниверситета, 2011. С. 30-41].

Antipin V.S., Voronin V.I., 2010. Patom Crater - the Earth or space origin? Nauka iz pervykh ruk 5 (35), 16 -25 (in Russian) [Антипин В.С., Воронин В.И. Патомский кратер - земной или небесный? // Наука из первых рук. 2010. Т. 5 . № 35. C. 16-25].

Antipin V.S., Voronin V.I., Fedorov A.M., 2008. Patom Crater in Eastern Siberia. Priroda 9, 69-75 (in Russian) [Антипин B.С., Воронин В.И., Федоров А.М. Патомский кратер в Восточной Сибири // Природа. 2008. № 9. С. 69-75].

Bemezhko D.Y., Ugryumov I.A., Bychkov S.G., 2011. Gravimetric studies of Patom Crater. In: Patom Crater. Research in the 21st Century. Publishing House of the Irkutsk State University, Irkutsk, p. 42-50 (in Russian) [Бемежко Д.Ю., Угрюмов И.А., Бычков С.Г. Гравиметрические исследования Патомского кратера // Патомский кратер. Научные исследования в XXI веке. Иркутск: Изд-во Иркутского госуниверситета, 2011. С. 42-50].

Borovikov L.N., 1974. Frost mounds in Kazakhstan, their development and decay. Materialy po geologii i poleznym iskopaemym Uznogo Kazakhstana (Materials on geology and mineral resources of the Southern Kazakhstan) 5 (30), 179-188 (in Russian) [Боровиков Л.Н. Мерзлотные бугры вспучивания в Казахстане, их развитие и отмирание // Материалы по геологии и полезным ископаемым Южного Казахстана. 1974. Т. 5. № 30. С. 179-188].

Dmitriev A.A., Dmitriev A.G., 2011. Analysis of results of regional geological and geophysical studies in the area of Patom Crater. In: Patom Crater. Research in the 21st Century. Publishing House of the Irkutsk State University, Irkutsk, p. 24 29 (in Russian) [Дмитриев А.А., Дмитриев А.Г. Анализ результатов региональных геолого-геофизических работ в районе Патомского кратера // Патомский кратер. Научные исследования в XXI веке. Иркутск: Изд-во Иркутского госуниверситета, 2011. С. 24-29].

Feldman G.M., 1988. Moisture movements in thawing and freezing soils. Nauka, Siberian branch, Novosibirsk, 258 p. (in Russian) [Фельдман Г.M. Передвижение влаги в талых и промерзающих грунтах. Новосибирск: Наука. Сибирское отделение, 1988. 258 с.].

Fotiev S.M., 2011. Geocryological chronicles of Russia. Earth Cryosphere 15 (4), 8-13.

French H.M., 2007. The periglacial environment. 2nd edition. John Wiley \& Sons, Ltd., England, 458 p.

Gevorkyan S.G., Koreysha M.M., 1993. Blowup of heaving mounds. Materialy Glyceologicheskih Issledovanii (Glaciological Research Materials) 77, 120-130 (in Russian) [Геворкян С.Г., Корейша М.M. Взрывы бугров пучения // Материалы гляциологических исследований. 1993. Вып. 77. С. 120-130].

Golubov B.N., Sapozhnikov Yu.A., Yazev S.A., 2011. The impact of a space object or subsurface dislocation? In pursuit of the mystery of Patom Crater. In: Patom Crater. Research in the 21st Century. Publishing House of the Irkutsk State University, Irkutsk, p. 51-63 (in Russian) [Голубов Б.Н., Сапожников Ю.А., Язев С.А. Удар космического тела или дислокация недр? К познанию тайны Патомского кратера // Патомский кратер. Научные исследования в XXI веке. Иркутск: Изд-во Иркутского госуниверситета, 2011. С. 51-63].

Gorbunov A.P., 1986. The cryzolitozone of the Central Asian region. Publishing House of the Permafrost Institute, SB RAS, Yakutsk, 58 p. (in Russian) [Горбунов А.П. Криолитозона Центрально-Азиатского региона. Якутск: ИМЗ СО АН CCCP, 1986. 58 c.].

Gorbunov A.P., 2006. Rock glaciers of the Asian Russia. Kriosfera Zemli 10 (1), 22-28 (in Russian) [Горбунов А.П. Каменные глетчеры Азиатской России // Криосфера Земли. 2006. Т. 10. № 1. С. 22-28].

Gordeev P.P., 1972. Swelling mounds in the Poluya river basin. In: Geocryological and Hydrogeological Research of Siberia. Yakutiya Publishing House, Yakutsk, p. 106-110 (in Russian) [Гордеев П.П. Бугры пучения в бассейне реки Полуя // Геокриологические и гидрогеологические исследования Сибири. Якутск: Якутское книжное изд-во, 1972. C. 106-110].

Gorelik J.B., 2009. Modelling of ice accumulation in freezing ground at injection moisture entry. Kriosfera Zemli 13 (3), 45 53 (in Russian) [Горелик Я.Б. Моделирование льдонакопления в промерзающих грунтах при инъекционном поступлении влаги // Криосфера Земли. 2009. Т. 13. № 3. С. 45-53].

Gorelik J.B., 2011. Simulating ice accumulation and deformations on ground freezing: a generalized theoretical model. Kriosfera Zemli 13 (4), 46-51 (in Russian) [Горелик Я.Б. Обобщенная теоретическая модель для расчета льдонакопления и деформаций при промерзании грунтов // Криосфера Земли. 2011. Т. 15. № 4. С. 46-51].

Grossvald M.G., 2003. Glaciation and volcanism of the Sayan-Tuva highland. Izvestiya Akademii Nauk. Seriya Geograficheskaya 2, 83-92 (in Russian) [Гросвальд М.Г. Оледенение и вулканизм Саяно-Тувинского нагорья // Известия 
Академии наук. Серия географическая. 2003. № 2. С. 83-92].

Hauber E., Reiss D., Ulrich M., Preusker F., Trauthan F., Zanetti M., Hiesinger H., Jaumann R., Johansson L., Johnsson A., Van Gasselt S., Olvmo M., 2011. Landscape evolution in Martian mid-latitude regions: insights from analogous periglacial landforms in Svalbard. In: M.R. Balme, A.S. Bargery, C.J. Gallagher, S. Gupta (Eds.), Martian Geomorphology. Geological Society, London, Special Publications 356, 111-131. http://dx.doi.org/10.1144/SP356.7.

Het Drentse Landschap Weichselien 120.000 - 11.000 v. Chr. 2012. http://www.drentslandschap.nl/Erfgoed/archeologie/ Weichselien.aspx.

Isaev V.P., Isaev P.V., 2011. Patom Volcano. In: Patom Crater. Research in the 21st century. Publishing House of the Irkutsk State University, Irkutsk, p. 64-72 (in Russian) [Исаев В.П., Исаев П.В. Патомский вулкан // Патомский кратер. Научные исследования в ХХІ веке. Иркутск: Изд-во Иркутского госуниверситета, 2011. С. 64-72].

Katasonov E.M., Soloviev P.A., 1969. Travel guide and excursions to Central Yakutia. Yakutiya Publishing House, Yakutsk, 85 p. (in Russian) [Катасонов E.M., Соловьев П.А. Путеводитель к экскурсии по Центральной Якутии. Якутск: Якутское книжное изд-во, 1969. 85 с.].

Kolpakov V.V., 1951. A mysterious crater in the Patom highland. Priroda 2, 58-59 (in Russian) [Колпаков В.В. Загадочный кратер в Патомском нагорье // Природа. 1951. № 2. С. 58-59].

Kolpakov V.V., Yazev S.A., 2007. Patom cone. Zemlya i Vselennaya 1, 57-65 (in Russian) [Колпаков В.В., Язев С.А. Патомский конус // Земля и Вселенная. 2007. № 1. С. 57-65].

Kosmachev K.P., 1953. Bulgunnyakhi (bulging mounds). Priroda 11, 111-112 (in Russian) [Космачев К.П. Булгунняхи (курганы выпучивания) // Природа. 1953. № 11. С. 111-112].

Kostromitin S., 2011. Patom Miracle. In: Istok. Ecology and Geography Newspaper. Issue 4 (86), p. 9 (in Russian) [Kocmромитин С. Патомское чудо // Исток. Эколого-географическая газета. 2011. № 4 (86). С. 9].

Krendelev F.P., Nasyrova R.A., 1985. Recent valley-type structures in the Chara basin. In: Udokan. Natural resources and their development. Nauka, Siberian Branch, Novosibirsk, p. 53-82 (in Russian) [Кренделев Ф.П., Насырова Р.А. Современные долинные образования Чарской котловины // Удокан. Природные ресурсы и их освоение. Новосибирск: Наука. Сибирское отделение, 1985. С. 53-82].

Krivonosov B.M., 1978. Tebelers in the Chuya steppe. In: Proceedings of the West Siberian Regional Scientific Research Hydrometeorological Institute, Issue 37. Gidrometeoizdat, Moscow, p. 87-90 (in Russian) [Кривоносов Б.М. Тебелеры в Чуйской степи // Труды Западно-Сибирского регионального научно-исследовательского гидрометеорологического института. Вып. 37. М.: Гидрометеоиздат, 1978. С. 87-90].

Krotova Z.A., Kandyba Yu.L., 1966. The Patom Crater study. Meteoretika (Meteorites Studies) 27, 134-138 (in Russian) [Кротова 3.А., Кандыба Ю.Л. Исследование Патомского кратера // Метеоритика. 1966. Вып. 27. С. 134-138].

Mackay J.R., 1965. Gas-domed mounds in permafrost, Kendall Island, N.W.T. Geographical Bulletin 7 (2), $105-115$.

Mackay J.R., 1973. The growth of pingos, western Arctic coast, Canada. Canadian Journal of Earth Sciences 10 (6), 979 1004. http://dx.doi.org/10.1139/e73-086.

Mackay J.R., 1988. The birth and growth of Porsild Pingo, Tuktoyaktuk Peninsula, District of Mackenzie. Arctic Institute of North America 41 (4), 267-274.

Mel'nikov P.I., Feldman G.M., Anisimova N.P., 1984. The formation of ice schlieren due to fluctuations on the boundary over the freezing water table. Doklady AN SSSR 279 (2), 476-480 (in Russian) [Мельников П.И., Фельдман Г.М., Анисимова Н.П. Формирование шлиров льда при колебаниях границы промерзания над уровнем грунтовых вод // Доклады АН СССР. 1984. Т. 279. № 2. С. 476-480].

Minaev A.N., 1963. Large ghydrolakkolites in the West Siberian lowland. In: Permafrost in various regions of the USSR. Publishing House of the USSR Academy of Sciences, Moscow, p. 160-165 (in Russian) [Минаев А.Н. Крупные гидролакколиты в Западно-Сибирской низменности // Многолетнемерзлые горные породы различных районов СССР. М.: Изд-во АН СССР, 1963. С. 160-165].

Mironov S.M., Ingerov O., Egorov A.S., Yermolin E.Yu., Sukhanov R.A., 2011. Preliminary results of geoelectric surveys conducted by 2010 Patom Crater expedition. In: Patom Crater. Research in the 21st century. Publishing House of the Irkutsk State University, Irkutsk, p. 73-85 (in Russian) [Миронов С.М., Ингеров О., Егоров А.С., Ермолин Е.Ю., Суханов P.A. Предварительные результаты электроразведочных работ АМТ-МВЗ экспедиции «Патомский кратер 2010» // Патомский кратер. Научные исследования в XXI веке. Иркутск: Изд-во Иркутского госуниверситета, 2011. C. 73-85].

Moiseenko A., 2011. Fire eagle’s nest. MetroFan 1 (4), 76-80 (in Russian) [Моисеенко А. Гнездо огненного орла // MетроФан, 2011. Т. 1. № 4. С. 76-80].

Moiseenko A., Yazev S., 2010. The Patom Crater riddle. «Piter», St. Petersburg, 256 p. (in Russian) [Моисеенко А., Язев C. Загадка Патомского кратера. СПб.: Питер, 2010. 256 с.].

Obruchev S.V., 1951. To V. Kolpakov’s article «The mysterious crater on Patom Plato». Priroda 2, 59-61 (in Russian) [Oбручев С.В. К статье В.В. Колпакова «Загадочный кратер на Патомском нагорье» // Природа. 1951. № 2. С. 59-61].

Pekhovich A.I., Razgovorova E.L., 1975. Physics of blowups of heaving mounds. In: Proceedings of the Coordination Meetings on Hydraulic Engineering. Vol. 101. Hydraulic Engineering in the Far North Regions. Energy, Leningrad, p. 143- 
147 (in Russian) [Пехович А.И., Разговорова Е.Л. Физика взрывов бугров пучения // Труды координационных совещаний по гидротехнике. Вып. 101. Гидротехническое строительство в районах Крайнего Севера. Л.: Энергия, 1975. С. 143-147].

Petrov V.G., 1930. Icing mounds at the Amur-Yakutsk Rail Road. Publishing House of the USSR Academy of Sciences and the Motor Road Scientific Research Institute of the People's Commissariat of the USSR, Leningrad, 177 p. (in Russian) [Петров В.Г. Наледи на Амуро-Якутской магистрали. Л.: Изд-во АН СССР и н.-и. автодорожного института НКПС СССР, 1930. 177 с.].

Petrov V.G., 1934. The experience in determining the pressure of ground water in icing mounds. In: Proceedings of the Permafrost Studies Commission. Publishing House of the USSR Academy of Sciences, Moscow, V. 2. p. 59-72 (in Russian) [Петров В.Г. Опыт определения силы давления грунтовых вод в наледях // Труды Комиссии по изучению вечной мерзлоты. М.: Изд-во АН СССР, 1934. Т. 2. С. 59-72].

Podkovyrov V., 2010. http://worldmystery.ru/forum/6-53; http://clubdruzey.ru/meet/index.php?topic=14.135 Подковыров В. Кратко о загадке Патомского кратера. 2010. http://worldmystery.ru/forum/6-53; http://clubdruzey.ru/meet/index.php? topic $=14.135$.

Porsild A.E., 1938. Earth mounds in unglaciated Arctic northwestern America. Geographical Review 28 (1), 46-58. http://dx. doi.org/10.2307/210565.

Portnov A.M., 1962. The crater at Patom highland. Priroda 11, 102-103 (in Russian) [Портнов А.М. Кратер на Патомском нагорье // Природа. 1962. № 11. С. 102-103].

Portnov A.M., 1964. About the crater on Patom highland. Meteoretika 25, 194-195 (in Russian) [Портнов A.M. О кратере на Патомском нагорье // Метеоритика. 1964. Вып. 25. С. 194-195].

Portnov A.M., 1993. Patom Crater - the trace of the Tunguska event? Zemlya i Vselennaya 1, 77-81 (in Russian) [Портнов A.M. Патомский кратер - след Тунгусского явления? // Земля и Вселенная. 1993. № 1. С. 77-81].

Rudoy A.N., 1988. About the age of tebelers age and the time of complete decay of ice-dammed lakes in the Altai. Izvestiya vsesoyuznogo geograficheskogo obshchestva 121 (40), 344-348 (in Russian) [Рудой А.Н. О возрасте тебелеров и времени окончательного исчезновения ледниково-подпрудных озёр на Алтае // Известия Всесоюзного географического общества. 1988. Т. 121. № 4. С. 344-348].

Rusanov B.S., 1961. Hydrothermal movements of the Earth surface. Publishing House of the USSR Academy of Sciences, Moscow, 226 p. (in Russian) [Русанов Б.С. Гидротермические движения земной поверхности. М.: Изд-во АН CCCP, 1961. 226 c.].

Savichev A.A., 2011. Patom Crater. In: Savichev A.A. (Ed.), Research in the 21st century. Publishing House of the Irkutsk State University, Irkutsk, 116 p. (in Russian) [Патомский кратер. Научные исследования в XXI веке / Под ред. А.А. Савичева. Иркутск: Изд-во Иркутского госуниверситета, 2011. 116 с.].

Savichev A.A., 2011. The geology, substance and the cryolitozone of Patom Crater - a clue to the phenomenon's riddle. In: Patom Crater. Research in the 21st Century. Publishing House of the Irkutsk State University, Irkutsk, p. 86-103 (in Russian) [Савичев А.А. Геология, вещество и криолитозона района Патомского кратера - ключ к разгадке феномена // Патомский кратер. Научные исследования в XXI веке. Иркутск: Изд-во Иркутского госуниверситета, 2011. С. 86103].

Soloviev P.A., 1952. Bulgunnyakhs of the Central Yakutia. In: Permafrost studies in the Yakutian Republic. Issue 3. Publishing House of the USSR Academy of Sciences, Moscow, p. 226-258 (in Russian) [Соловьев П.А. Булгунняхи Центральной Якутии // Исследование вечной мерзлоты в Якутской республике. Вып. 3. М.: Изд-во АН СССР, 1952. С. 226-258].

Stremyakov A.Ya., 1964. The giant swelling mound in the north of the Chukostka Peninsula. In: Geocryological conditions of Western Siberia, Yakutia and Chukotka. Nauka, Moscow, p. 134-139 (in Russian) [Стремяков А.Я. Гигантский бугор пучения на севере Чукотского полуострова // Геокриологические условия Западной Сибири, Якутии и Чукотки. М.: Наука, 1964. С. 134-139].

Sukhodrovsky V.L., 1964. Swelling mounds in the Franz Josef Land. Materialy glyaciologicheskih issledovanij 10, 285-286 (in Russian) [Суходровский В.Л. Бугры пучения на Земле Франца-Иосифа // Материалы гляциологических исследований. 1964. Вып. 10. С. 285-286].

Sumgin M.I., 1927. Permafrost soils in the USSR. Vladivostok, 372 p. (in Russian) [Сумгин М.И. Вечная мерзлота почвы в пределах СССР. Владивосток, 1927. 372 с.].

Sumgin M.I., 1940. To the theory of formation of perennial ice mounds called bulgunnyakhs. Doklady AN SSSR 28 (2), 155156 (in Russian) [Сумгин М.И. К теории образования многолетних наледных бугров-булгунняхов // Доклады АН СССР. 1940. T. 28. № 2. С. 155-156].

Sumgin M.I., Demchinsky B.N., 1940. The permafrost area. Glavmorsevput Publishing House, Moscow-Leningrad, 237 p. (in Russian) [Сумгин М.И., Демчинский Б.Н. Область вечной мерзлоты. М.-Л.: Изд-во Главморсевпути, 1940. 237 c.].

Tarakanov A.G., 1981. Swelling mounds in the Sonkal basin (Tien Shan). Izvestiya Vsesoyuznogo Geograficheskogo Obshchestva 113 (1), 48-52 (in Russian) [Тараканов А.Г. Бугры пучения Сонкальской котловины (Тянь-Шань) // Известия Всесоюзного географического общества. 1981. Т. 113. № 1. С. 48-52]. 
Uddelermeer, not just a lake! 2007. http://www.geocaching.com/seek/cache_details.aspx?guid=fd1bce8a-794c-412f-b067229bbffb74bf.

Ugryumov I.A., Demezhko D.Yu., 2011. The local geodynamic network at Patom Crater. In: Patom Crater. Research in the 21st Century. Publishing House of the Irkutsk State University, Irkutsk, p. $48-50$ (in Russian) [Угрюмов И.А., Демежко Д.Ю. Локальная геодинамическая сеть на Патомском кратере // Патомский кратер. Научные исследования в XXI веке. Иркутск: Изд-во Иркутского госуниверситета, 2011. С. 48-50].

Vasilchuk Yu.K., Budantseva N.A., 2010. Radiocarbon dating of the pingo in the Pestsovoye gas field in the north of West Siberia. Engineering Geology, 2 (July), 14-21.

Voronin V.L., 2006. Preliminary results of dendrochronological analysis of Larix dahurica saw-cut samples collected in the Patom Crater area. Selected Problems of Astronomy. Proceedings of the Sky and the Earth Conference dedicated to the 75th anniversary of the Astronomical Observatory of the Irkutsk State University. Irkutsk, 2006. p. 169-176 (in Russian) [Воронин В.Л. Предварительные результаты дендрохронологического анализа спилов лиственницы даурской, отобранных в районе Патомского кратера. Избранные проблемы астрономии. Материалы научно-практической конференции «Небо и Земля», посвященной 75-летию астрономической обсерватории ИГУ. Иркутск, 2006. С. 169-176].

Vtyurin B.I., 1975. Ground ice of the USSR. Nauka, Moscow, 214 p. (in Russain) [Втюрин Б.И. Подземные льды СССР. М.: Наука, 1975. 214 с.].

Washburn A.L., 1979. Geocryology. A survey of periglacial processes and environments. London, 406 p.

William G., Holmes W.G., Hopkins D.M., Foster H.L., 1968. Pingos in Central Alaska - contributions to general geology. United States Government printing office, Washington, D.C., 40 p.

Yazev S.A., 2011. Patom Crater. A brief history of research. In: Patom Crater. Research in the 21st century. Publishing House of the Irkutsk State University, Irkutsk, p. 12-23 (in Russian) [Язев С.А. Патомский кратер. Краткая история исследований // Патомский кратер. Научные исследования в XXI веке. Иркутск: Изд-во Иркутского госуниверситета, 2011. C. 12-23].

Yoshikawa K., Leuschen C., Ikeda A., Harada K., Gogineni P., Hoekstra P., Hinzman L., Sawada Y., Matsuoka N., 2006. Comparison of geophysical investigations for detection of massive ground ice (pingo ice). Journal of Geophysical Research 111 (E6), E06S19. http://dx.doi.org/10.1029/2005je002573.

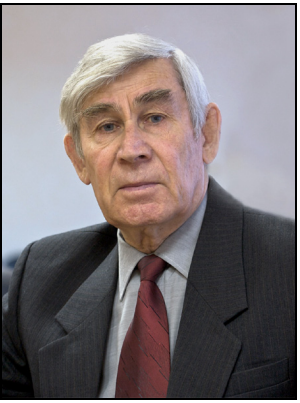

Алексеев Владимир Романович, докт. геогр. наук, профессор, г.н.с.

Институт мерзлотоведения им. П.И. Мельникова СО РАН

677010, Якутск, ул. Мерзлотная, 36, Россия

Институт географии им. В.Б. Сочавы СО РАН

664033, Иркутск, ул. Улан-Баторская, 1, Россия

Тел.: (3952)427767; $₫$ e-mail: Snow@Irk.ru

Alekseyev, Vladimir R., Doctor of Geography, Professor, Chief Researcher

P.I. Melnikov Permafrost Institute, SB RAS

6 Merzlotnaya street, Yakutsk 677010, Russia

V.B. Sochava Institute of Geography, SB RAS

1 Ulan-Batorskaya street, Irkutsk 664033, Russia

Tel.: (3952)427767; $\bowtie$ e-mail: Snow@Irk.ru 